\title{
Dual Shell Reactor Vessel: A Pressure- Balanced System for High Pressure and Temperature Reactions
}

\author{
R. J. Robertus \\ A. G. Fassbender \\ G. S. Deverman
}

March 1995

Prepared for

the U.S. Department of Energy

under Contract DE-AC06-76RLO 1830

Pacific Northwest Laboratory

Richland, Washington 99352 



\section{DISCLAIMER}

Portions of this document may be illegible in electronic image products. Images are produced from the best available original document. 


\section{Summary}

The main purpose of this work was to demonstrate the Dual Shell Pressure Balanced Vessel (DSPBV) as a safe and economical reactor for the hydrothermal water oxidation of hazardous wastes. Experimental tests proved that the pressure balancing piston and the leak detection concept designed for this project will work.

The DSPBV was sized to process $10 \mathrm{gal} / \mathrm{hr}$ of hazardous waste at up to $399^{\circ} \mathrm{C}\left(750^{\circ} \mathrm{F}\right)$ and $5000 \mathrm{psia}$ $(34.5 \mathrm{MPa}$ ) with a residence time of $10 \mathrm{~min}$. The first prototype reactor is a certified ASME pressure vessel. It was purchased by Innotek Corporation (licensee) and shipped to Pacific Northwest Laboratory (PNL) for testing. Supporting equipment and instrumentation were, to a large extent, transported here from Battelle Columbus Division. A special air feed system and liquid pump were purchased to complete the package. The entire integrated demonstration system was assembled at PNL.

During the activities conducted for this report, the leak detector design was tested on bench top equipment. Response to low levels of water in oil was considered adequate to ensure safety of the pressure vessel.

Shakedown tests with water only were completed to prove the system could operate at $350^{\circ} \mathrm{C}$ at pressures up to $3300 \mathrm{psia}$. Two demonstration tests with industrial waste streams were conducted, which showed that the DSPBV could be used for hydrothermal oxidation. In the first test with a metal plating waste, chemical oxygen demand, total organic carbon, and cyanide concentrations were reduced over $90 \%$. In the second test with a munitions waste, the organics were reduced over $90 \%$ using $\mathrm{H}_{2} \mathrm{O}_{2}$ as the oxidant. 



\section{Acknowledgments}

This work was prepared as part of TTP No. RL342004 with the support of the following contributors:

Headquarters:

Operations Office:

Coordinating Office:

Contractor:
Office of Technology Development Supercritical Water Oxidation Program Jaffer Mohiuddin, Program Manager

Richland Operations Office Technology Development Division

Deborah E. Trader, Technical Program Officer

Idaho National Engineering Laboratory Supercritical Water Oxidation Program John M. Beller, Program Coordinator

Pacific Northwest Laboratory Environmental Management Directorate Steven C. Slate, Technical Program Manager 



\section{Contents}

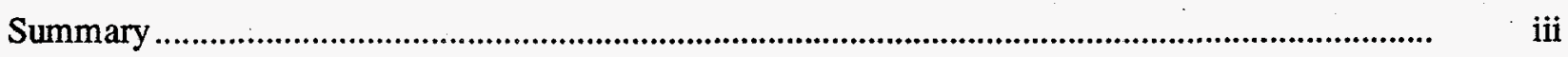

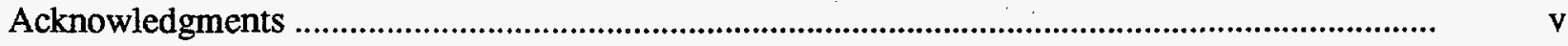

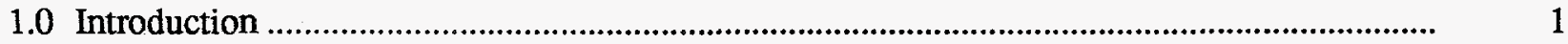

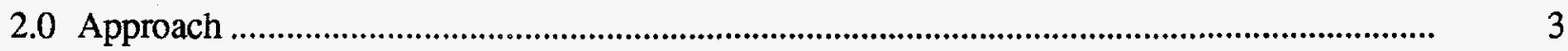

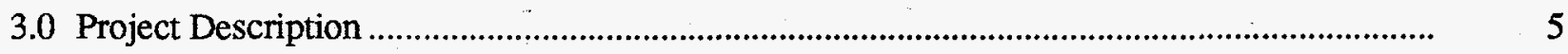

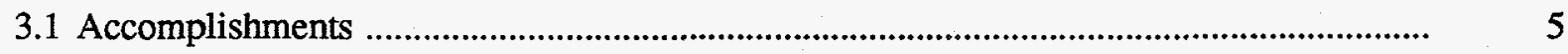

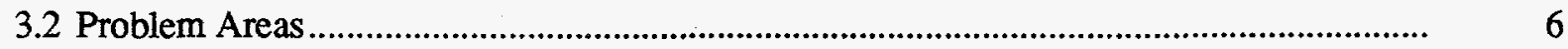

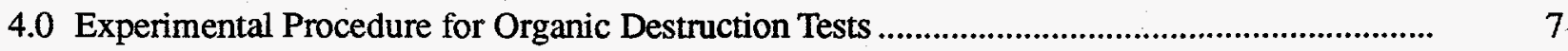

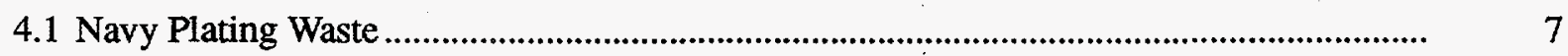

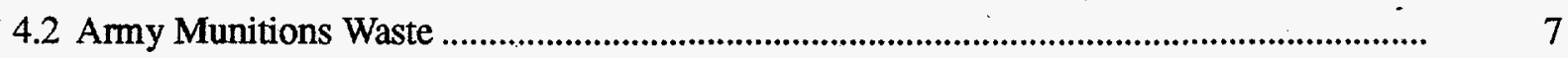

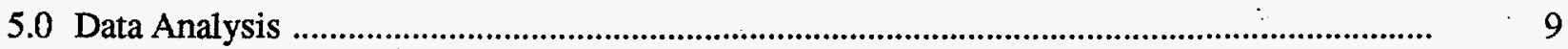

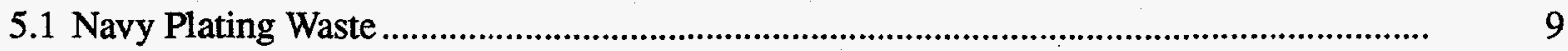

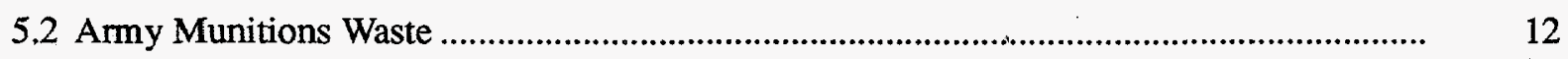

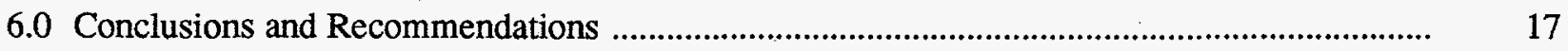

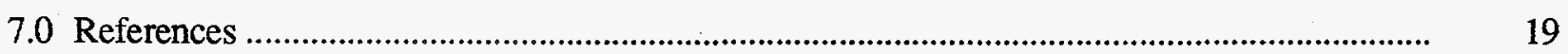

Appendix - Description of the Dual-Shell Pressure-Balanced Vessel .......................................... A.1 


\section{Figures}

5.1 Key to Abbreviations Used in Temperature Plots of Figures 5.3 and 5.6 ...........................

5.2 Recorded Pressures at Feed, Reactor, and Letdown Vessel .............................................. 10

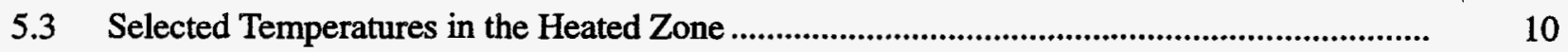

5.4 Determination of Flow Rate of Waste Material to the Reactor .......................................... 11

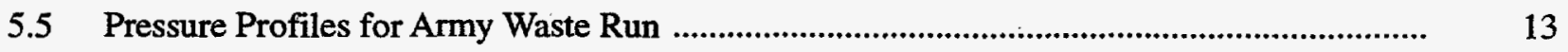

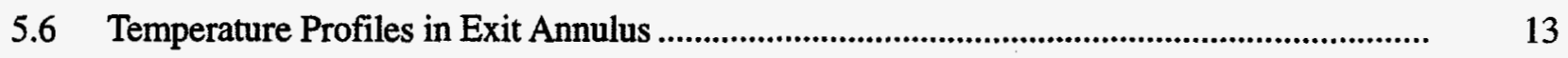

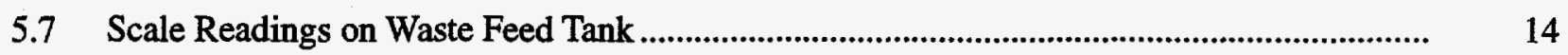

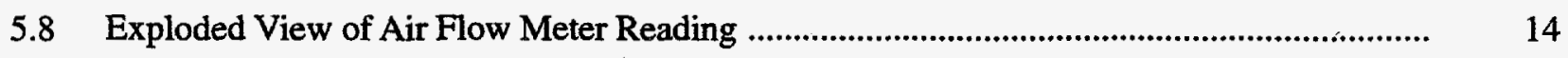

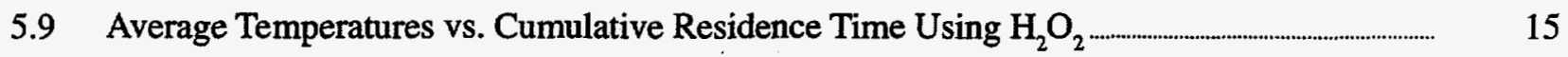

5.10 Average Temperatures as a Function of Cumulative Residence Time Using Air ................. 15

\section{Tables}

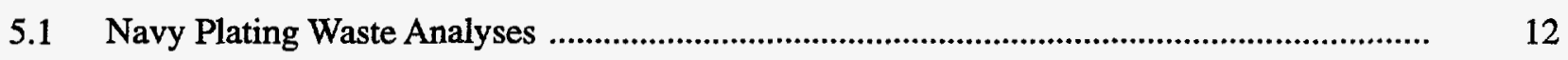

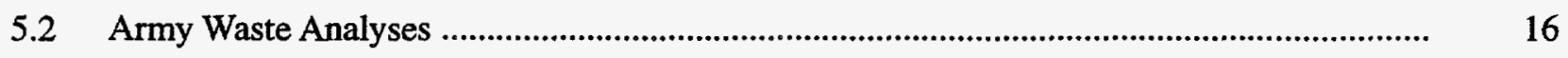




\subsection{Introduction}

Many commercial processes require a pressure vessel capable of operating in a corrosive environment where safety and economy are important requirements. Hydrothermal chemical reactions such as wet-air oxidation and supercritical water oxidation occur in a highly corrosive environment inside a pressure vessel. Average corrosion rates from 23 to 80 mils per year in conventional reaction vessels have been reported by Rice et al. (1994) and Latanision and Shaw (1993). The actual observed corrosion is often uneven, and pitting is sometimes seen. In addition, 316 stainless steel, Inconel 625, and Hastelloy C-276 have exhibited stress-corrosion cracking when used as pressure vessels for hydrothermal processes. Differential thermal expansion, uneven corrosion, pitting, and stress-corrosion cracking limit the use of linings in vessels to provide corrosion protection. Undetected breached linings could lead to prolonged hidden corrosion of the pressure vessel.

Battelle engineers at Pacific Northwest Laboratory (PNL) ${ }^{(a)}$ have developed and patented (U.S. patent 5,167,930 Dec. 1, 1992) a novel Dual Shell Pressure Balanced Vessel (DSPBV), which could overcome the many problems with pressure vessels, such as those cited above. Additionally, the DSPBV inherently solves the high cost problem associated with all-alloy reactors by using conventional steels for the pressure barrier and thin walled (relatively inexpensive) alloy shells to contain the reacting fluid. Sensors in the pressure balancing fluid will detect when the critical alloy thin shell is breached. The design of the vessel allows quick replacement of the thin shells, so a "new" reactor costs only a fraction of first unit.

The main purpose of the work described in this report was to demonstrate the DSPBV as a safe and economical reactor for the hydrothermal water oxidation of hazardous wastes. This report contains a description of the DSPBV and its supporting equipment (also see Appendix) as well as summary data from two demonstration runs. In these runs, organics in a metal plating waste from the Navy and a munitions waste stream from the Army were destroyed by hydrothermal water oxidation.

Innotek Corporation of Little Rock, Arkansas, is the licensee for DSPBV reactor technology. For the demonstration study, Innotek purchased a pressure vessel (ASME certified) with Incoloy 825 thin shells surrounded by a $11 / 4$ Cr-1/2 Mo carbon steel shell.

The DSPBV was sized to process $10 \mathrm{gal} / \mathrm{hr}$ of hazardous waste at up to $399^{\circ} \mathrm{C}\left(750^{\circ} \mathrm{F}\right)$ and $5000 \mathrm{psia}$ (34.5 MPa) with a residence time of $10 \mathrm{~min}$. Most of the supporting equipment and instrumentation were obtained from Battelle Columbus Division. A special air feed system and liquid pump were purchased to complete the package. The entire demonstration system was then put together at PNL.

(a) Operated for the U.S. Department of Energy by Battelle Memorial Institute under Contract DE-AC06-76RLO 1830. 



\subsection{Approach}

Efforts described in this report were part of a much larger national Super Critical Water Oxidation (SCWO) program aimed at treatment of hazardous wastes at a variety of government sites. Other projects investigated modeling of reactors, operation of small-scale high temperature systems, and reactor operation with high solids content products, as well as other more generic issues pertaining to hydrothermal water oxidation. The primary objective of the PNL work was to demonstrate that the DSPBV would function safely as designed. The demonstration equipment was designed to process $10 \mathrm{gal} / \mathrm{hr}$ of liquid wastes with residence times of about $10 \mathrm{~min}$ at pressures up to 5000 psia and temperatures up to $399^{\circ} \mathrm{C}$. The space between the inner alloy liner and the outer pressure vessel shell of the DSPBV is filled with a pressure balancing fluid. An external piston moves to keep pressure on the pressure balancing fluid (Syltherm $800^{\circledR}$ ) and the reacting fluid inside the liner equal. Most of the pressure differential during operation is due to unequal thermal expansion of the two fluids.

A conductivity meter (or a capacitance probe) was inserted in the pressure balancing fluid to monitor leaks in the inner shell. Any sudden changes in the measurement of that property of the pressure transfer fluid would indicate that the thin shell has been breached and the vessel should be shut down for repairs. Commercial probes will not operate at the temperatures and pressures needed for this task. Instead, the sensor was custom designed to interface with off-the-shelf electronics.

Reactor corrosion is recognized as a significant problem in SCWO. This reaction vessel has been designed for simple replacement of thin shells made of different alloys. Thickness of each thin shell can be measured before and after a series of runs to determine overall corrosion rates. Thickness measurements as a function of axial position in the reactor will provide detailed corrosion information because temperatures are also recorded as functions of axial position. Areas of accelerated corrosion should be obvious from the thickness measurements. Magnified visual inspection of the thin shells will provide useful qualitative information. 



\subsection{Project Description}

The project was organized into a design phase, a planning and documentation phase, and an experimental testing phase. The results of the design phase of the DSPBV are covered in the Appendix. Planning accomplishments are noted below. Experimental testing is described in Sections 4.0 and 5.0.

\subsection{Accomplishments}

The DSPBV was built with an inner shell that fits close to the wall of the outer shell of the pressure vessel made of carbon steel. A pressure-transfer fluid is placed in the annulus between the pressure vessel and the Incoloy 825 inner shell. The pressure-transfer fluid is kept physically separate and in hydrostatic equilibrium with the fluid entering the reactor by using an external pressure-balancing piston. While the pressure-transfer fluid balances the pressure, its electrical properties are continuously monitored to ensure the integrity of the inner shell. A significant change in conductivity of the pressure-transfer fluid alerts operators to a breach of the inner shell so it can be replaced before the carbon steel pressure vessel corrodes. The ability to continuously monitor the integrity of the working reactor is a fundamental safety advance in reactor design.

The leak detector design uses a high surface to volume ratio so small changes in resistance can be detected. Syltherm 800 is a very poor electrical conductor. Hence, an ohmmeter attached to the electrodes reads as an open circuit until water enters the oil. Absolute detection limits were not established, but qualitatively a mixture of $<1 \%$ tap water and $99 \%$ Syltherm showed instant conductivity. This sensitivity was deemed adequate to protect the outer pressure wall if the inner shell developed any holes from corrosion or weld failure.

Specific planning activities carried out for this study included preparing NEPA documentation, a Risk Assessment, and a Safe Operating Procedure, which were then approved by appropriate personnel. Impact levels were justified and approved by Quality Assurance staff. The Test Plan was also completed and approved. It called for a series of tests which would verify operation of the pressure balancing concept while simultaneously generating engineering information needed to scale up the reactor.

Tests with hot water were completed as set forth in the Test Plan. Innotek funded tests for destruction of two military wastes. Summary results from those tests are included herein as evidence that the reactor can destroy organic materials.

Successful operation of the DSPBV has launched a project involving design and construction of a pilot-scale version of the DSPBV. This is seen as the first and critical step toward commercialization of the DSPBV. 


\subsection{Problem Areas}

During the design phase, initial cost estimates for support equipment were determined. These estimates were much lower than actual costs. The high equipment costs prevented completion of some scheduled tests, namely, tests with Hanford wastes.

Several instrument failures were encountered and caused delays in getting the system operational. Leaks at high pressure prevented the system from operating as early as planned. Two fittings in the top head of the reactor vessel were particularly troublesome to seal. The system eventually was made leak free by re-threading several holes and changing pipe sealant materials. 


\subsection{Experimental Procedure for Organic Destruction Tests}

Two quite different aqueous waste streams were processed to demonstrate that the DSPBV can indeed destroy organic waste materials in water streams. Both tests supported a defined need in the Department of Defense and were funded separately by Innotek as a step toward commercialization of the DSPBV.

\subsection{Navy Plating Waste}

Approximately 30 gal of waste material from a Navy metal plating operation were received in a steel drum and analyzed shortly afterward. Next, some tests were performed in a batch autoclave to determine the amount of oxidant required to destroy the cyanide and the organics. The material was processed in the DSPBV about 2 weeks later. Samples were taken at 1-hr intervals and analyzed later that day or early the next day. Temperature, pressure, and flow data were recorded at 1-min intervals using an automated data acquisition system.

The batch autoclave experiments showed that $\sim 2 \mathrm{ml}$ of $\mathrm{H}_{2} \mathrm{O}_{2}$ were required per liter of waste to destroy the cyanide. In the batch tests, nitric acid was also added to react with the nitrogen present as ammonia. The same technique was used in the DSPBV.

A typical run in the DSPBV requires about $2 \mathrm{hr}$ to reach operating pressure at room temperature. The system is checked thoroughly for leaks. Then an internal heater is switched on to start heating the fluid. An additional $3 \mathrm{hr}$ are required to heat the system to $350^{\circ} \mathrm{C}$. This heatup procedure is done using plain water. Finally the feed tank is switched to the actual waste material to be processed. Depending on flow rates, another 1 to $3 \mathrm{hr}$ are required to flush out the water and process "pure" waste. Analytical data from outlet samples define when the transition occurred. After the waste is processed, the system is simultaneously cooled and flushed with pure water before depressurizing and shutting down. For this particular test, more exact times for each of these steps can be determined from the figures shown in Section 5.0.

\subsection{Army Munitions Waste}

About 45 gal of waste containing approximately $300 \mathrm{ppm}$ ethanol, $30 \mathrm{ppm}$ diethyl ether, and $60 \mathrm{ppm}$ 2,4-DNT (di-nitro toluene) were received. Batch tests were run to determine the amount of oxidant required to destroy the organic constituents. In the DSPBV run, a portion of the waste was treated with $\mathrm{H}_{2} \mathrm{O}_{2}$ and the remainder with air.

During both experimental tests, a leak detector was in place, but never detected any water in the pressure balancing fluid. This is reasonable because the total run time was short enough that corrosion should not have penetrated the thin shell. More runs under highly corrosive conditions are needed to test the leak detector on the DSPBV. 



\subsection{Data Analysis}

This section summarizes data obtained while processing the two waste streams obtained from the Navy and the Army. Operating data are presented graphically, while analytical data are shown in tables. Because each test was run at essentially one condition, no kinetic information or other modeling parameters were determined.

\subsection{Navy Plating Waste}

Temperature and pressure data were monitored continuously as the experiment progressed. They were logged to a data file at 1-min intervals for later analyses. A key to the temperature/pressure profile acronyms is shown in Figure 5.1. Figures 5.2 through 5.4 show system profiles with time. It is clear that

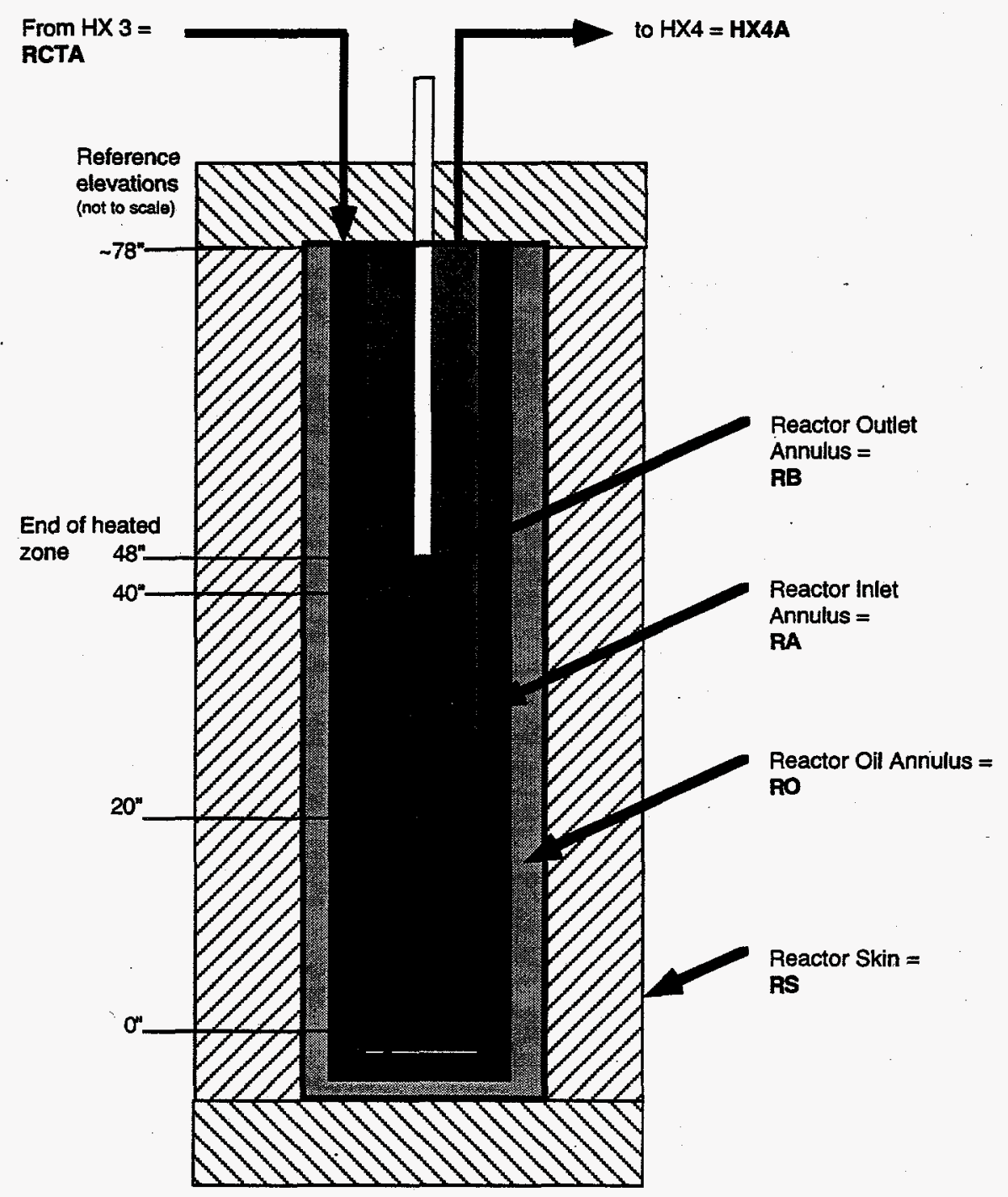

Figure 5.1. Key to Abbreviations Used in Temperature Plots of Figures 5.3 and 5.6 


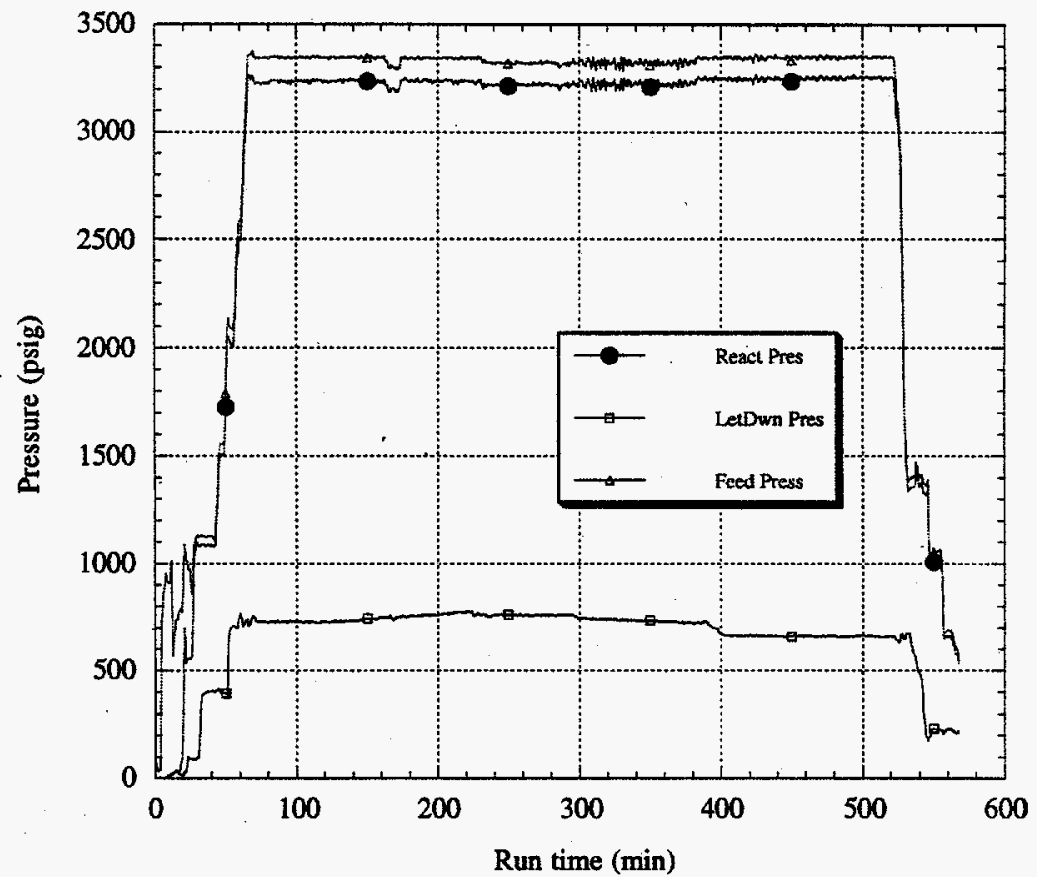

Figure 5.2. Recorded Pressures at Feed, Reactor, and Letdown Vessel

US Navy plating waste

16 Sep 94

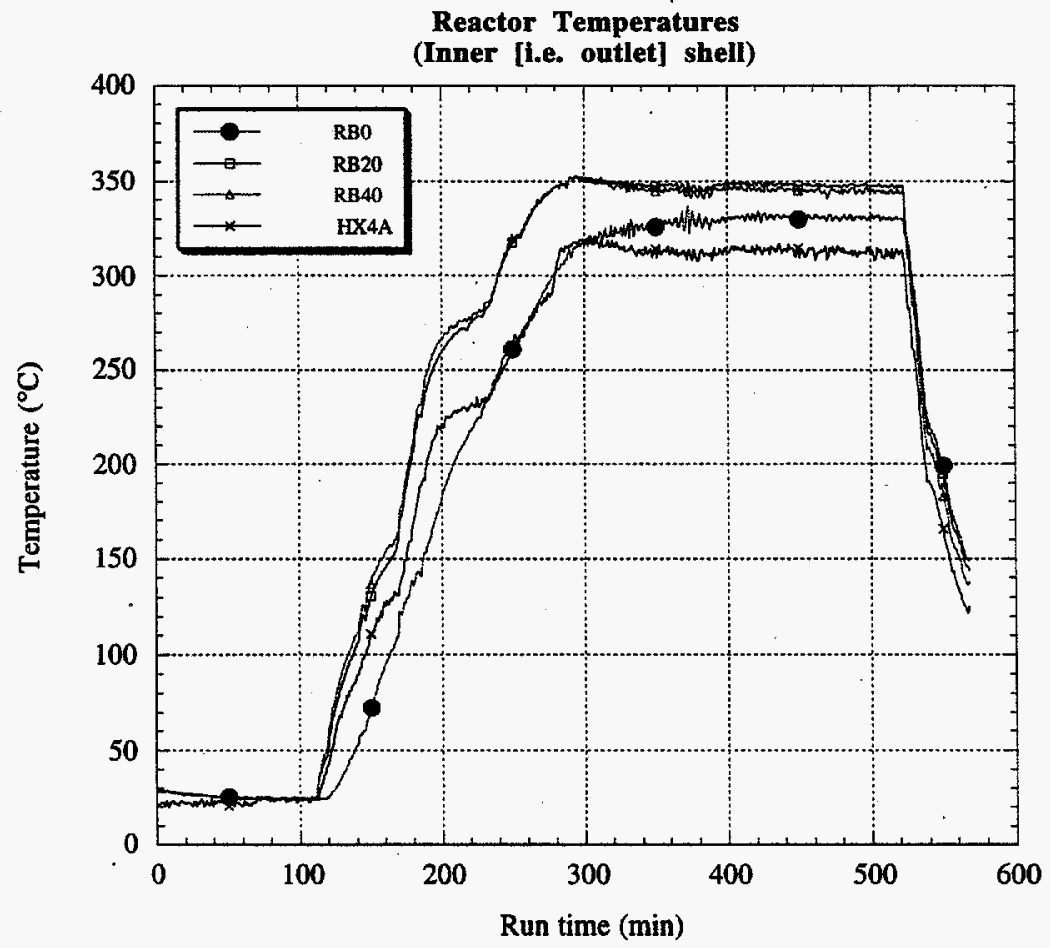

Figure 5.3. Selected Temperatures in the Heated Zone 


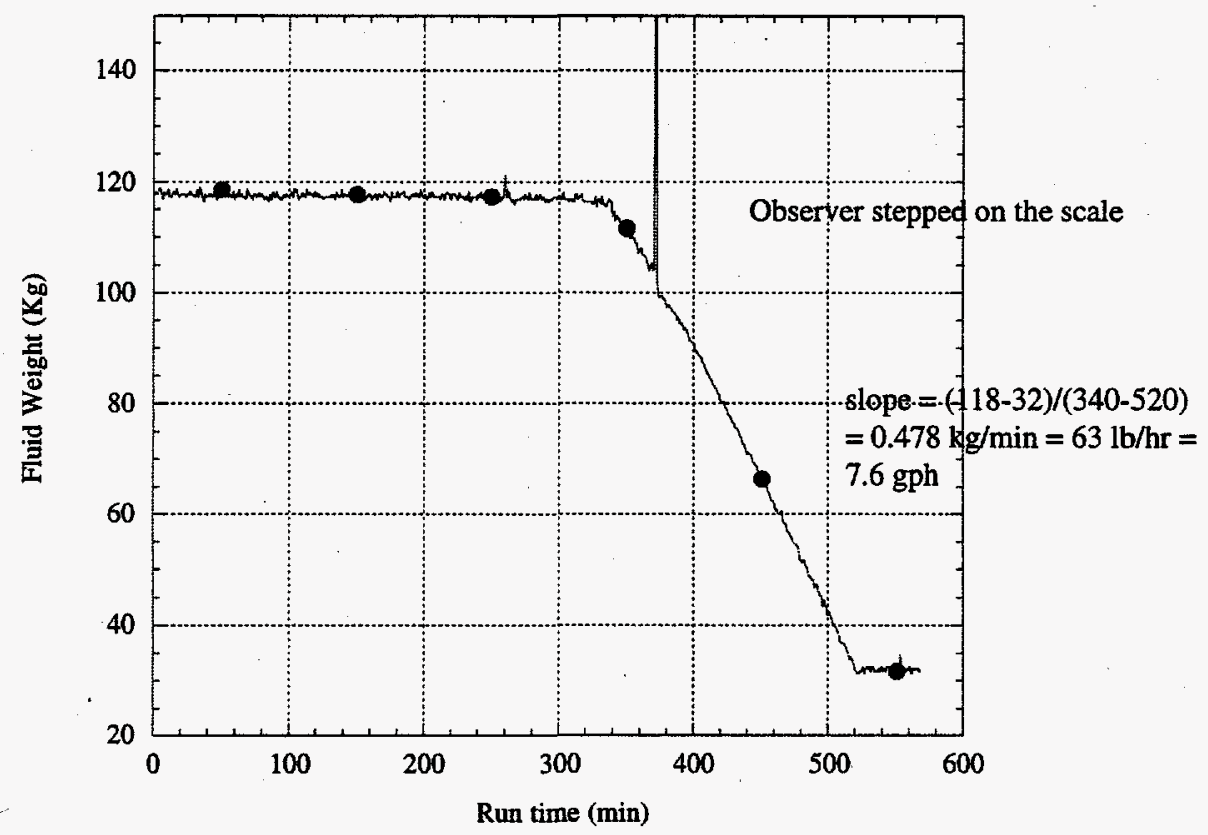

Figure 5.4. Determination of Flow Rate of Waste Material to the Reactor

about $4 \mathrm{hr}$ of steady-state operation were achieved for the Navy test. Table 5.1 shows analytical data for the run. The "as received" data are actually the waste composition the day of the DSPBV run. The time designation on the samples is time after start of the waste feed (not total operation time).

The switch from water feed to waste feed can be deduced from Figure 5.4. Pressure and temperature profiles in Figures 5.2 and 5.3 show that the system was at thermal and hydraulic steady-state before the switch was made. Data in Table 5.1 indicate that chemical reaction steady-state was achieved sometime between 2 and $3 \mathrm{hr}$ after start of the waste feed. This is the time required to flush the system of the pure water used to heat up the reactor.

Table 5.1 gives the overall analysis of the Navy waste, including chemical oxygen demand (COD), total organic carbon (TOC), total carbon (TC), and cyanide (CN) concentration. COD is a test used to determine the amount of oxygen that will be consumed by a waste stream. The test requires no knowledge of the detailed chemical composition of the waste. Organic materials and dissolved metals will all consume oxygen.

TOC is a measure of the organic carbon present in the waste. TC includes all the organic carbon, but can include carbon from inorganic carbonate species as well. Hence, TC should always be larger than (or at least as large as) TOC. If organic materials are being destroyed, COD, TOC, and TC should all decrease. This did indeed happen during the test.

The cyanide concentration in the feed the day of the run was much lower than expected. Originally a concentration of about $5 \mathrm{ppm}$ was expected. The day the waste drum arrived, a sample was analyzed and found to contain $\sim 1 \mathrm{ppm}$ free cyanide. One explanation for the change in cyanide concentration may be 
Table 5.1. Navy Plating Waste Analyses

\begin{tabular}{|l|r|r|r|r|r|}
\hline Sample & $\mathrm{NH}_{4}$ as N & \multicolumn{1}{c|}{$\mathrm{COD}$} & \multicolumn{1}{c|}{ TOC } & \multicolumn{1}{c|}{ TC } & \multicolumn{1}{c|}{ CN } \\
\hline & $\mathrm{mg} / \mathrm{L}$ & $\mathrm{mg} / \mathrm{L}$ & $\mathrm{mg} / \mathrm{L}$ & $\mathrm{mg} / \mathrm{L}$ & $\mathrm{mg} / \mathrm{L}$ \\
\hline Feed as received & 3.5 & 50 & 15.11 & 80.05 & 0.064 \\
\hline $\begin{array}{l}\text { Feed treated with } \\
\mathrm{HNO}_{3} \text { and } \mathrm{H}_{2} \mathrm{O}_{2}\end{array}$ & 3.56 & 21 & 8.64 & 29.29 & $<0.005$ \\
\hline product after $\mathrm{hr}$ & & & & & \\
\hline product after $2 \mathrm{hr}$ & 0.67 & 7 & 2.46 & 14.38 & $<0.005$ \\
\hline product after $3 \mathrm{hr}$ & 0.57 & 5 & 1.15 & 3.45 & $<0.005$ \\
\hline
\end{tabular}

$\mathrm{COD}=$ chemical oxygen demand

TOC $=$ Total Organic Carbon

$\mathrm{TC}=$ Total Carbon

$\mathrm{CN}=$ total free cyanide

that the solution was not basic enough to "freeze" the cyanide. Analytical procedures call for keeping solutions at a minimum of $\mathrm{pH} 12$ to preserve cyanide. The $\mathrm{pH}$ of the waste was measured after the fact and found to be only about 8 . Most of the original cyanide may have hydrolyzed before the DSPBV test was run. Addition of $\mathrm{HNO}_{3}$ to the feed destroyed the rest. Nonetheless, the DSPBV run did show that organic materials could be destroyed at modest temperatures.

\subsection{Army Munitions Waste}

Figures 5.5 and 5.6 show pressure and temperature profiles for the Army munitions waste stream. Scale readings on the waste feed tank are given in Figure 5.7. The air injection process perturbed both the pressure and temperature profiles for a time. Problems occurred while trying to stabilize the air flow. The initial erratic behavior shows clearly in Figure 5.8. When the flow did stabilize at just above 3 SLM we assumed excess air was being added over the calculated (@ 50\% excess) 1.9 SLM needed to destroy the organics. In reality because of an unnoticed leak, the air flow to the reactor was closer to 0.6 SLM. This is probably the main explanation for the reduction in destruction efficiency using air, as seen in Table 5.2. Figures 5.9 and 5.10. show another contributing factor. The residence time (arbitrarily defined here as time above $300^{\circ} \mathrm{C}$ ) was longer for the $\mathrm{H}_{2} \mathrm{O}_{2}$ portion of the run. Although the liquid feed rate was slowed, the slower rate didn't quite compensate for the reduction in reacting volume when air is injected.

Table 5.2 also indicates that the nitrogen from the 2,4-DNT is forming nitrate ion. Other work has shown that conversion of nitrate ion to molecular nitrogen is possible by adding stoichiometric amounts of ammonia. The final form of the nitrogen for this test was known after the fact, so addition of $\mathrm{NH}_{3}$ was not attempted.

The Appendix shows the air injection point is at the bottom of the inner thin shell. Hence, the reacting volume is just in the inner chamber. When $\mathrm{H}_{2} \mathrm{O}_{2}$ is used, the reaction can also proceed in the outer water annulus when temperatures are high enough. Another contributing factor to the lower destruction efficiency could be the poorer distribution (mixing) of $\mathrm{O}_{2}$ from air compared to $\mathrm{O}_{2}$ from the $\mathrm{H}_{2} \mathrm{O}_{2}$. There was insufficient information to evaluate mixing effects. 


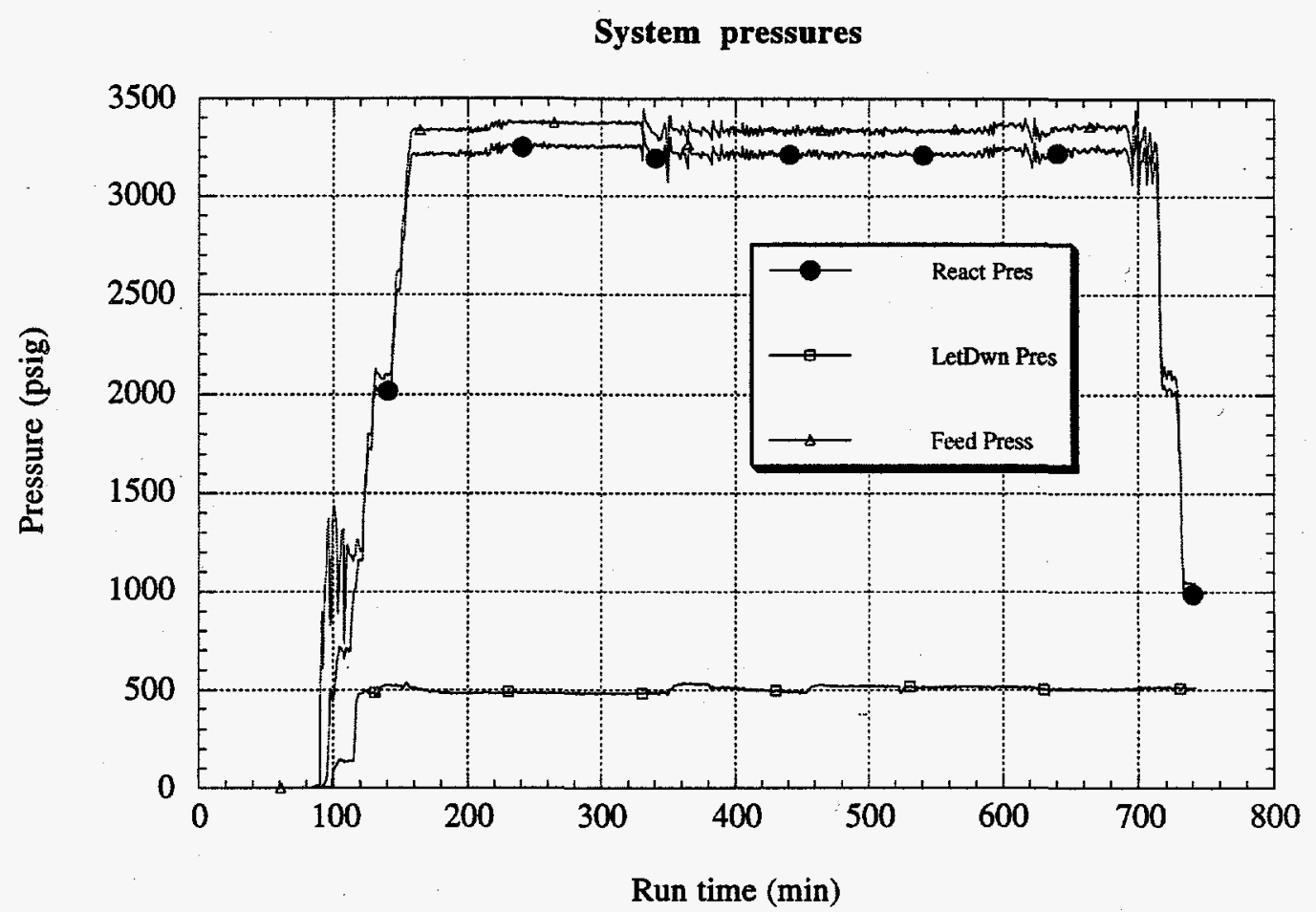

Figure 5.5. Pressure Profiles for Army Waste Run

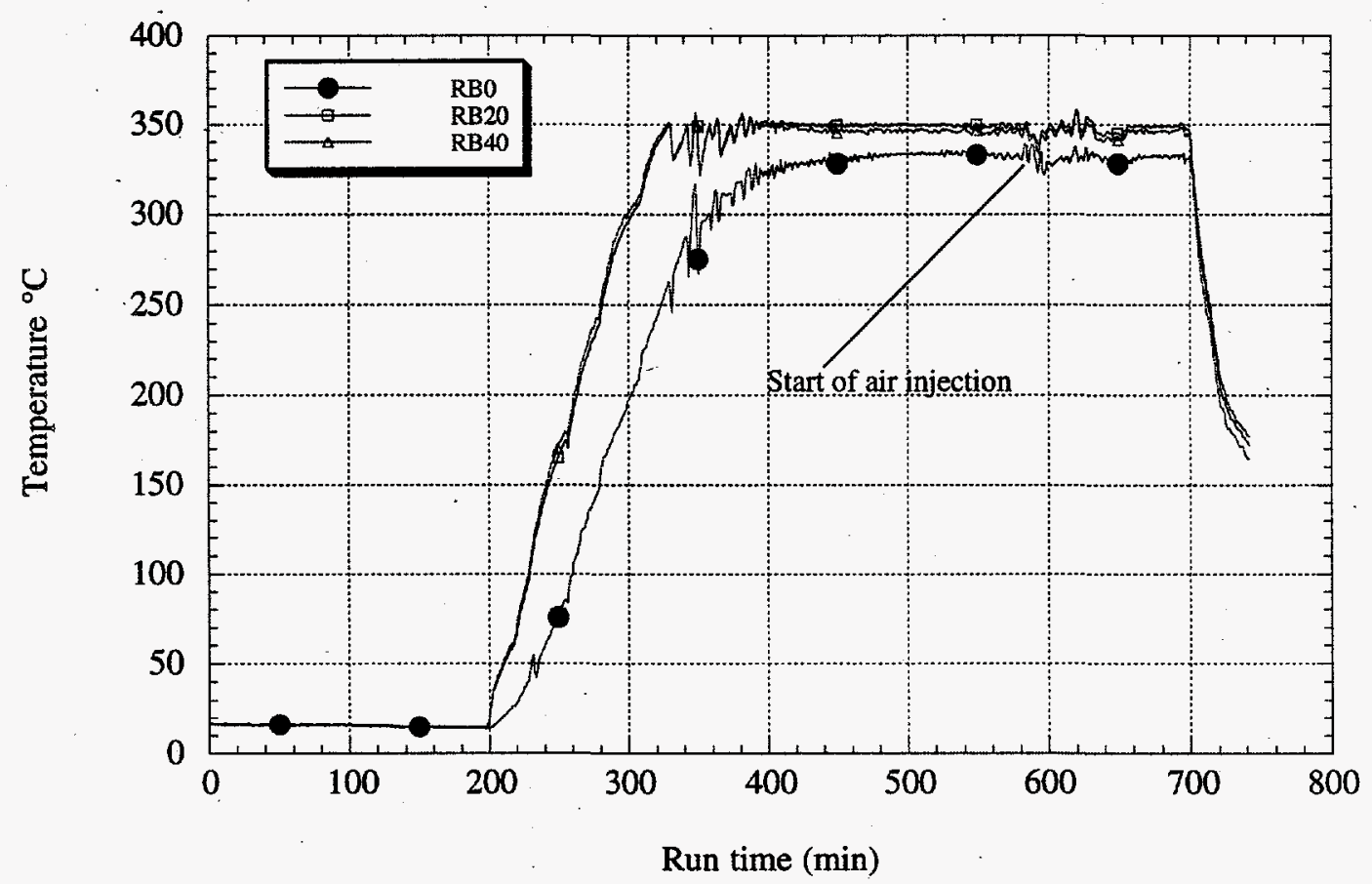

Figure 5.6. Temperature Profiles in Exit Annulus 


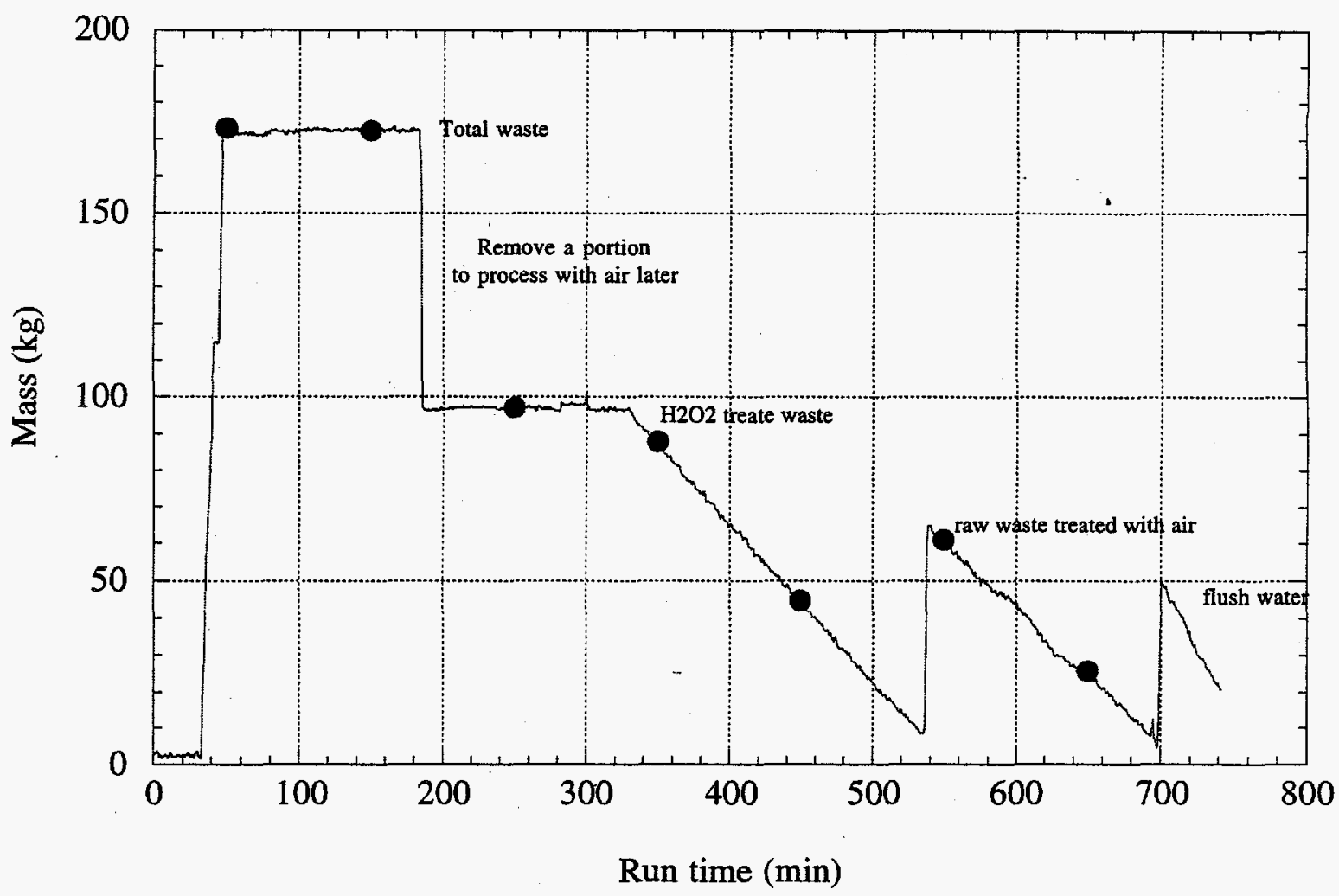

Figure 5.7. Scale Readings on Waste Feed Tank

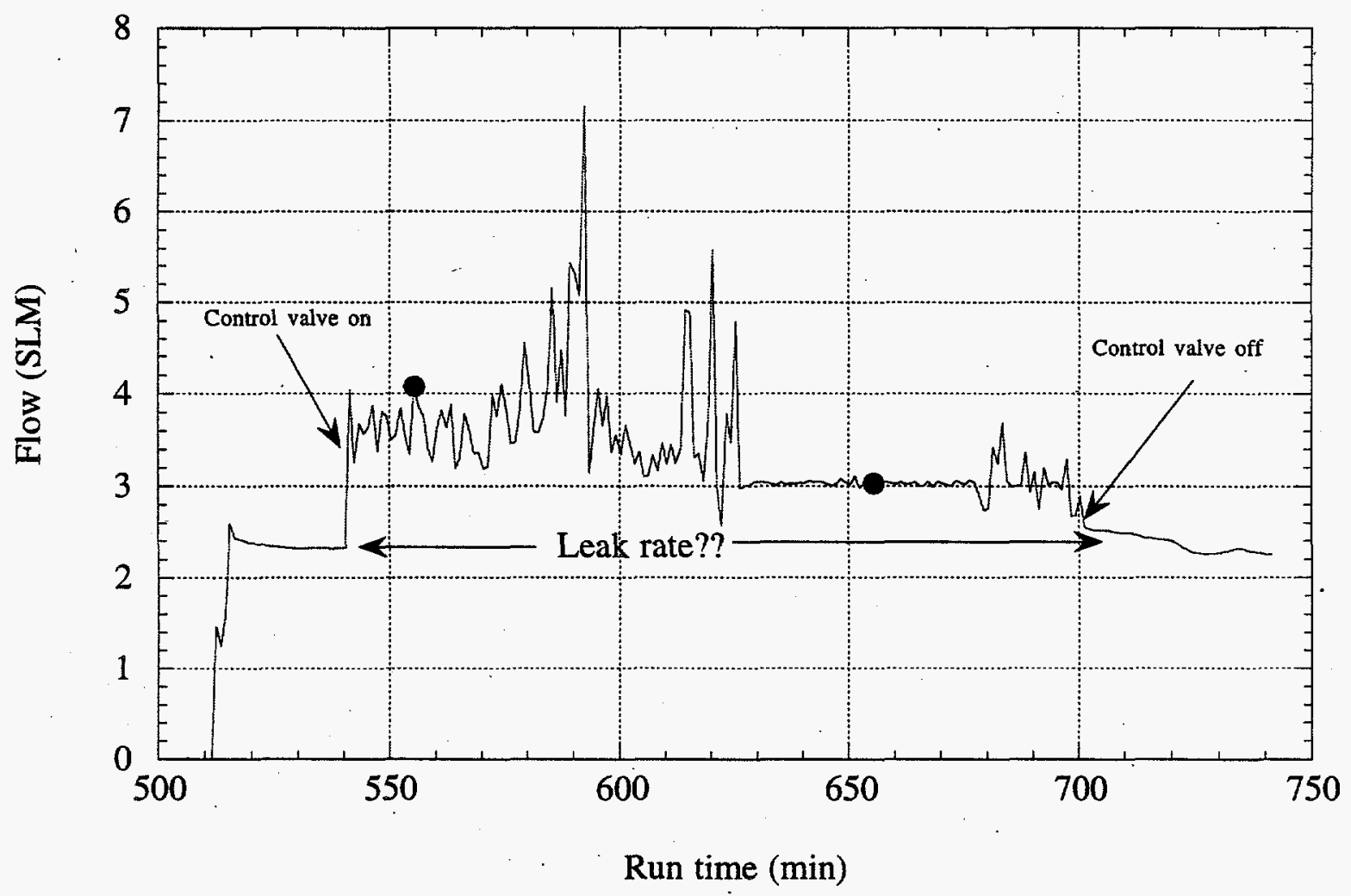

Figure 5.8. Exploded View of Air Flow Meter Reading 


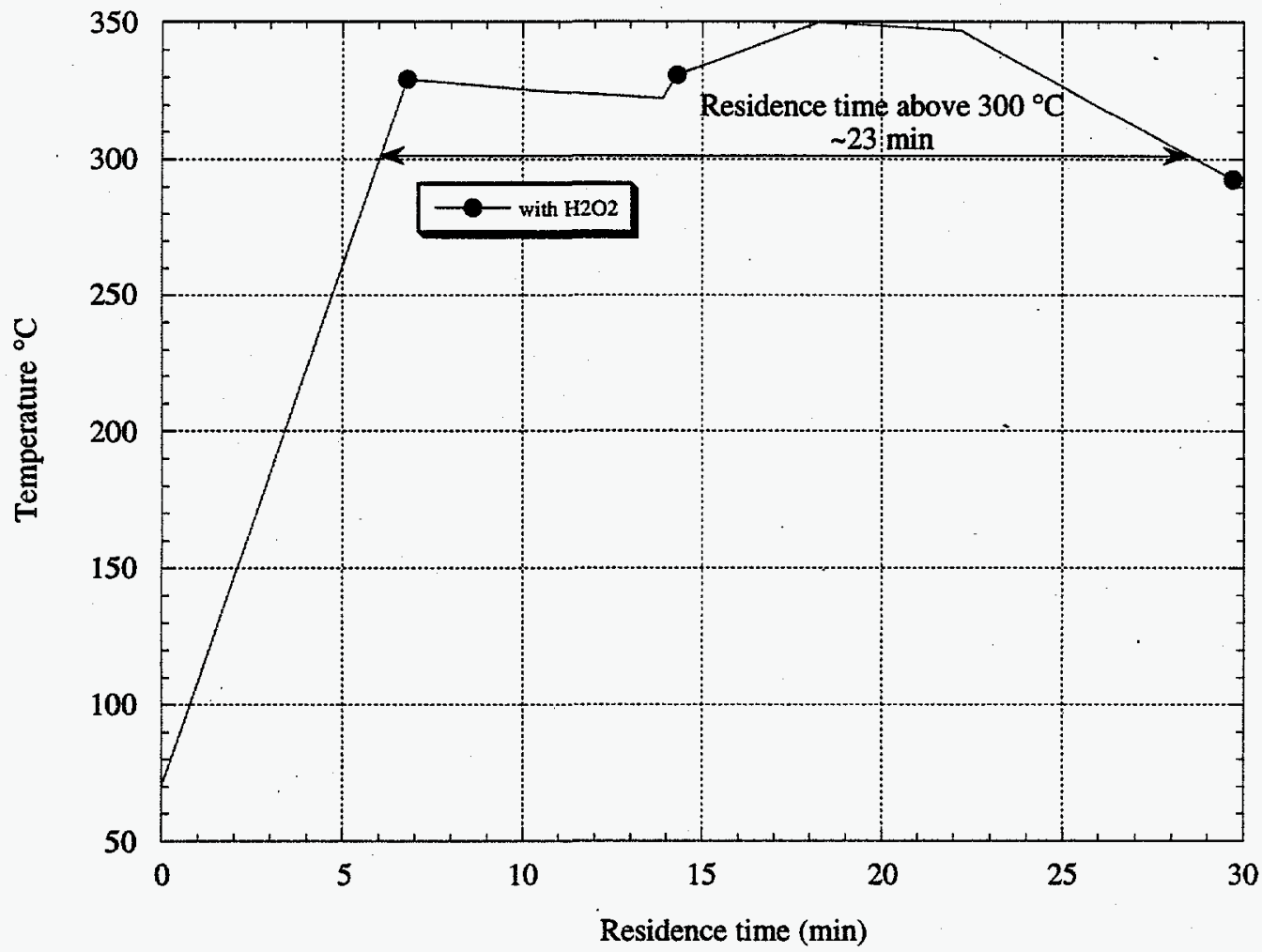

Figure 5.9. Average Temperatures vs. Cumulative Residence Time Using $\mathrm{H}_{2} \mathrm{O}_{2}$

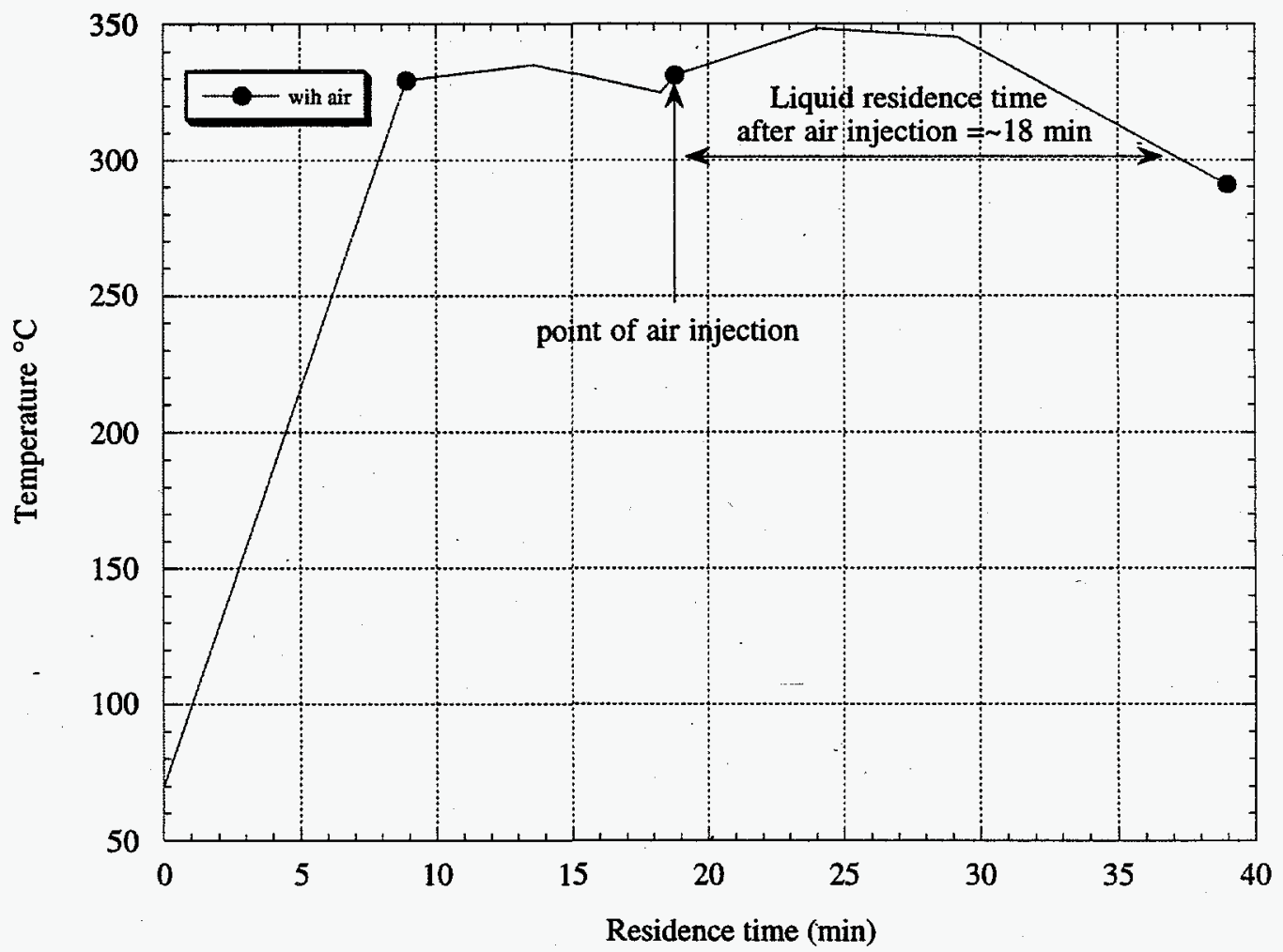

Figure 5.10. Average Temperatures as a Function of Cumulative Residence Time Using Air 
Table 5.2. Army Waste Analyses

\begin{tabular}{|l|r|r|r|r|r|}
\hline Sample & $\mathrm{pH}$ & $\mathrm{COD}$ & \multicolumn{1}{c|}{$\mathrm{TC}$} & \multicolumn{1}{c|}{ TOC } & $\mathrm{NO}_{3^{-}}$ \\
\hline & & $\mathrm{mg} / \mathrm{L}$ & $\mathrm{mg} / \mathrm{L}$ & $\mathrm{mg} / \mathrm{L}$ & $\mathrm{mg} / \mathrm{L}$ \\
\hline Feed as received & 6.90 & 680 & 180 & 140 & 0.17 \\
\hline $\begin{array}{l}\text { Feed treated with } \\
\mathrm{H}_{2} \mathrm{O}_{2}\end{array}$ & 7.48 & 1320 & 170 & 150 & 0.77 \\
\hline product after $1 \mathrm{hr}$ & 5.54 & 42 & 26 & 17 & 13.6 \\
\hline product after 2 $\mathrm{hr}$ & 5.55 & 48 & 32 & 23 & 15.6 \\
\hline product after 3 $\mathrm{hr}$ & 5.50 & 48 & 31 & 24 & 15.2 \\
\hline $\begin{array}{l}\text { product at end of } \\
\mathrm{H}_{2} \mathrm{O}_{2}\end{array}$ & 5.5 & 48 & 35 & 22 & 15.0 \\
\hline $\begin{array}{l}\text { product at air } \\
\text { start (4 hr) }\end{array}$ & 5.48 & 48 & 33 & 26 & 15.0 \\
\hline product after 5 hr & 5.81 & 111 & 52 & 41 & 7.53 \\
\hline product after 6hr & 5.82 & 112 & 59 & 43 & 5.48 \\
\hline
\end{tabular}

COD $=$ Chemical Oxygen Demand

TOC = Total Organic Carbon

TC = Total Carbon

$\mathrm{NO}_{3}{ }^{-}=$Nitrate ion 


\subsection{Conclusions and Recommendations}

The two demonstration tests conducted with military waste streams illustrated that the DSPBV and its supporting equipment are capable of destroying organic materials in aqueous waste streams. The pressure balancing concept was proven as a functional pressure vessel design.

Corrosion testing was initiated by measuring the thin shell thickness before the testing started. Both tests with real wastes were of short duration, and we believe no meaningful corrosion data would be obtained by opening the vessel. More operating time is needed to justify that effort and expense.

Additional work is needed using air as the oxidant to determine mixing effectiveness in the DSPBV geometry. More concentrated waste streams (in terms of organic materials) should be processed to experience temperature spikes and the associated control problems.

Successful destruction of the military waste streams has brought the DSPBV one step closer to commercialization. Innotek is now leading an effort to build and install a pilot-scale facility. 
8 


\subsection{References}

Latanision, R. M., and R. W. Shaw. 1993. Corrosion in Supercritical Water Oxidation Systems. Workshop Summary, MIT-EL 93-006, Massachusetts Institute of Technology, Cambridge, Massachusetts.

Rice, S. F., et al. 1994. Supercritical Water Oxidation of Colored Smoke, Dye, and Pyrotechnic Compositions. SAND94-8209, Sandia National Laboratory, Sandia, New Mexico. 


\section{Appendix \\ Description \\ of the}

\section{Dual-Shell Pressure-Balanced Vessel (DSPBV)}

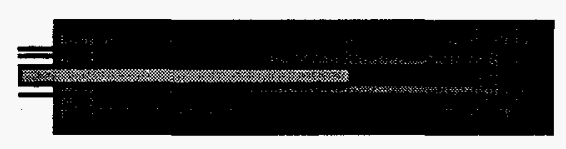

also known as the

\section{Dual Shell Reactor (DSR)}




\section{Appendix}

\section{Description of the Dual-Pressure-Balanced Vessel (DSPBV)}

The Dual Shell Pressure-Balanced Vessel (DSPBV) was developed to test and demonstrate a novel reactor design for moderate temperature, high-pressure, corrosive conditions. The DSPBV utilizes electrical heat and an oxidant to convert an aqueous organic feedstock into clean water and an exhaust gas composed of mainly nitrogen and carbon dioxide. Conversion occurs at moderate temperature $\left(350^{\circ} \mathrm{C}-400^{\circ} \mathrm{C}\right)$ and high pressure $(3500-4000 \mathrm{psi})$. The DSPBV is designed to process $10 \mathrm{gal} / \mathrm{hr}$ of dilute organic waste in water.

The initial objective of the test system was to prove that the DSPBV concept will work safely in corrosive environments. Further objectives are to determine potential waste destruction efficiencies for various aqueous organic feedstocks that might be encountered in Hanford waste streams. Municipal sewage sludge effluent treatment is another targeted feedstock. Feedstocks that may be tested vary from dilute organic chemical bearing water wastes containing from 100 to 100,000 ppm organic contaminants to sewage sludge effluents having about $5 \%$ dry solids. Each feedstock is evaluated on an individual basis for environmental and health hazards. Testing with aqueous organic waste feedstocks takes place in the Materials Reliability Center (MRC) at Pacific Northwest Laboratory. The results generated from the testing will be used for design of larger scale treatment facilities.

\section{A.1 Test Facility Description}

The MRC contains a $100 \mathrm{ft}$ by $50 \mathrm{ft}$ high bay with adjoining office space. The building is conditioned with evaporative coolers and forced-air electric heaters mounted on the roof. The high bay contains a crane with a 20 -ton capacity and $30-\mathrm{ft}$ hook height, with access to the entire high bay floor area. The available utilities are:

- Richland city water for process and cooling water

- $480 \mathrm{~V}, 208 \mathrm{~V}$, and $120 \mathrm{~V}$ electrical power

- 100 psig compressed air

- Sewer connections to the Richland publicly owned treatment works (POTW).

The MRC facility contains a sprinkler-water fire control system connected to the city water main.

\section{A.2 Test System Description}

Figure A.1 is a construction print for the DSPBV. The DSPBV uses a separate inner shell that fits close to the wall of the outer shell of the pressure vessel made of $11 / 4 \mathrm{Cr}-1 / 2$ Mo carbon steel (SA182 F11). The inner shell is constructed of Incoloy 825 (SB423, 424, 425). A pressure-transfer fluid, 


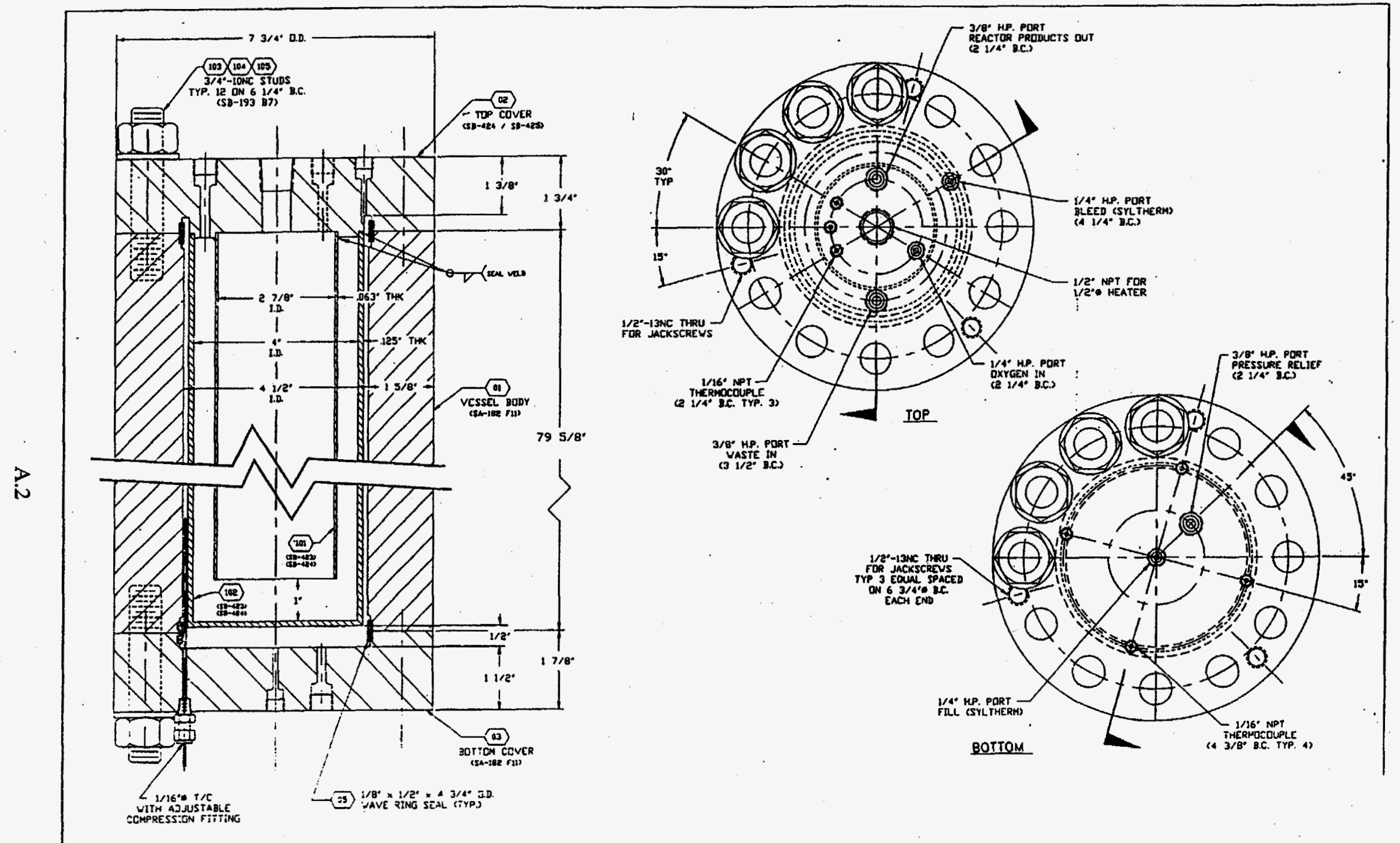

Figure A.1. DSR Construction Print 
Syltherm 800 , is placed in the annulus between the pressure vessel and the Incoloy 825 inner shell. The pressure-transfer fluid is kept physically separate and in hydrostatic equilibrium with the fluid entering the reactor. The pressure balancing is achieved by an external piston. Because the fluid pressure is balanced on both sides of the inner shell, the inner shell is not under significant stress; therefore, stresscorrosion cracking is minimized. The inner shell's thickness is determined by corrosion potential rather than strength; thus, it must only be thick enough to support its own weight and act as an envelope to separate the corrosive reactants from the carbon steel pressure vessel. The DSPBV design provides adequate space between the inner shell and the pressure vessel to allow for any degree of differential thermal expansion. The strength and corrosion resistance specifications of the pressure vessel are decoupled from the specifications of the inner shell.

While the pressure-transfer fluid balances the pressure, its electrical properties are continuously monitored to ensure the integrity of the inner shell. A significant change in conductivity of the pressuretransfer fluid alerts operators to a breach of the inner reactor so it can be replaced before the carbon steel pressure vessel corrodes. The ability to continuously monitor the integrity of the working reactor is a fundamental safety advance in reactor design.

The DSPBV working reactor unit is designed to monitor, protect, and preserve the integrity of the carbon steel pressure vessel. The working inner shell is designed for easy replacement as needed. The removable inner shell allows us to test alternate liner materials easily and inexpensively.

The DSPBV reactor is a test system designed for obtaining proof-of-principle information as well engineering data for the conversion of aqueous organic feedstocks into harmless gases and recyclable water. Capacity of the test system is $10 \mathrm{gal} / \mathrm{hr}$ liquid feed with a design flow rate of $10 \mathrm{gal} / \mathrm{hr}$. Design working conditions are reactor temperatures of $700-750^{\circ} \mathrm{F}$ at $3500 \mathrm{psi}$. The DSPBV was built to ASME pressure vessel code for operation up to $750^{\circ} \mathrm{F}\left(399^{\circ} \mathrm{C}\right)$ and 5000 psia.

Figure A.2 shows a sketch of the fundamental pieces involved in the pressure balanced piston design. Other options studied but rejected for either time or money considerations included 1) a bellows, 2) a sliding o-ring seal, and 3) the inner shells with a stationary o-ring seal (instead of welds used in the final design).

The equipment illustrated in Figure A.2 can be grouped into six categories for purposes of discussion:

- the main reactor and pressure balancing piston

- process feed tanks; pump, and heat exchanger

- Syltherm supply tank

- high-pressure air supply system

- pressure letdown equipment

- instrumentation.

Figure A.3 shows schematically a picture of the main supporting equipment for the DSPBV. This includes the air supply system and the pressure letdown vessel. 


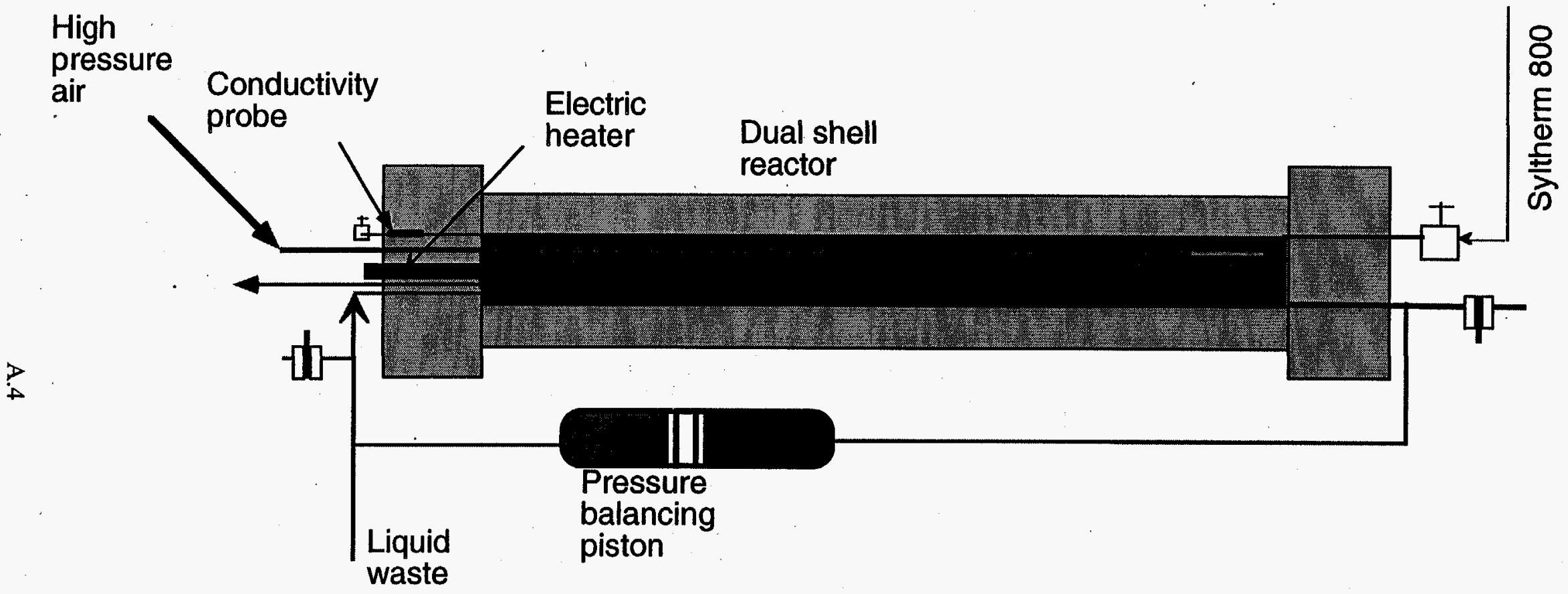

Figure A.2. Schematic of Reactor and Pressure-Balancing Piston 

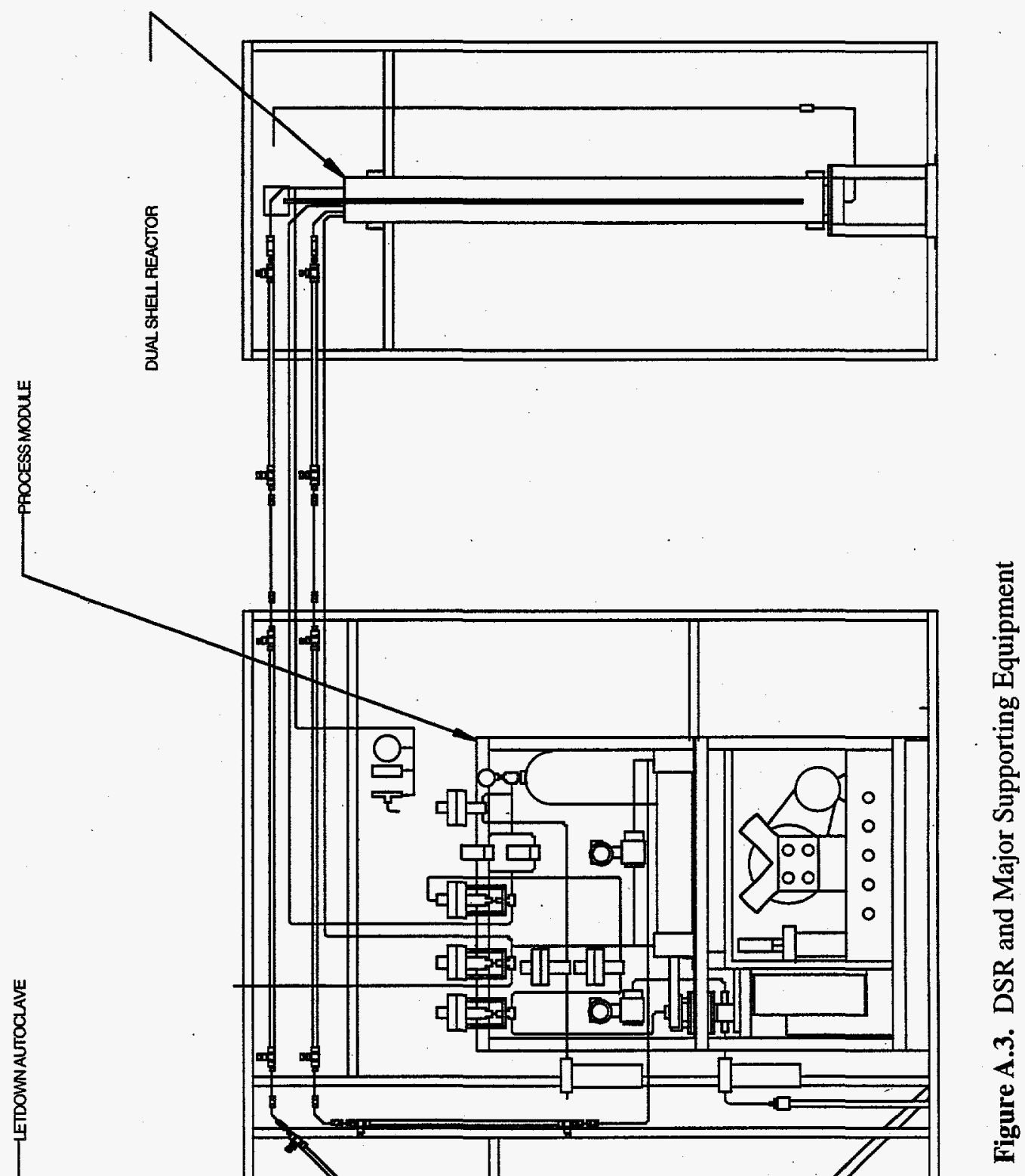


\section{A.2.1 Process Feed Tanks and Pump}

The process feed tank is polyethylene with a 50-gal capacity and has a metal lid to minimize evaporation into the room. The process feed tank is on an electronic scale which is tied to the data acquisition system. Weight readings are used to provide values for process feed flowrate to the reactor.

A second tank made of polyethylene contains deionized (DI) water for startup and for flushing out the reactor between runs. The flushing is done after each run to cool the reactor. A third tank is used to recirculate water through the shell of the product coolers and feed preheaters.

The process feed pump is an air operated, high-pressure, positive displacement pump. It will normally operate off building air and requires 28 SCFM at full capacity. The pump can be safely operated for at least $10 \mathrm{~min}$ using air from the storage cylinders of the high-pressure air system. This will allow safe shutdown of the system in the event of failure of the building air compressor. The tanks and pump are shown in Figure A.4.

\section{A.2.2 Syltherm Supply Tank}

The Syltherm supply tank is a carbon steel vessel protected with a safety relief valve that releases at 5 psig. The vessel is designed to have a nitrogen purge. When the reactor annulus is to be filled with Syltherm, a small pump whose suction line is in the Syltherm supply tank forces Syltherm into the bottom and out the top of the reactor. When the reactor annulus and pressure balancing piston are full, the fill valves at the top and bottom of the reactor are closed.

\section{A.2.3 High-Pressure Air Supply System}

The air supply system is an industrial unit typically used to fill self-contained breathing tanks for fire departments. The system can deliver up to 4 ACFM air at 6000 psig. The compressor is designed for intermittent use only. Consequently, two ASME vessels have been included to hold $~ 300$ SCF (150 SCF each) air at $6000 \mathrm{psig}$. \{Our operating storage tank pressure will be closer to $4000 \mathrm{psig}$ \}. Typical air consumption rates will be $\sim 2$ SCFM, so the demands on the compressor will not be too frequent once the tanks are full.

The complete air supply system is shown schematically in Figure A.5. The air compressor module including the two process air supply tanks has its own internal gauges and sensors to protect it from overpressure, or over-temperature. It also cycles periodically (every $15 \mathrm{~min}$ ) to remove liquid water that may have collected in the compressor. Outlet gas from the compressor to the air supply tanks is filtered to remove any entrained oil from the compressor.

\section{A.2.4 Pressure Letdown Equipment}

Product exiting the reactor passes through three heat exchangers. These heat exchangers share shell side fluid with another set of heat exchangers designed to preheat the incoming feed. Pressure letdown after cooling occurs in two stages. The first stage will drop the pressure from 5000 psia to 2500 psia across the main pressure regulating valve. This will release some dissolved gases (primarily $\mathrm{CO}_{2}$ ). From there, the two-phase mixture will pass through a final heat exchanger and then expand into a 2-gal autoclave where liquid and gases will separate. Pressure on the autoclave is determined by the pressure set on the gas stream outlet. Liquid flow out the system is determined by the liquid level sensor. 


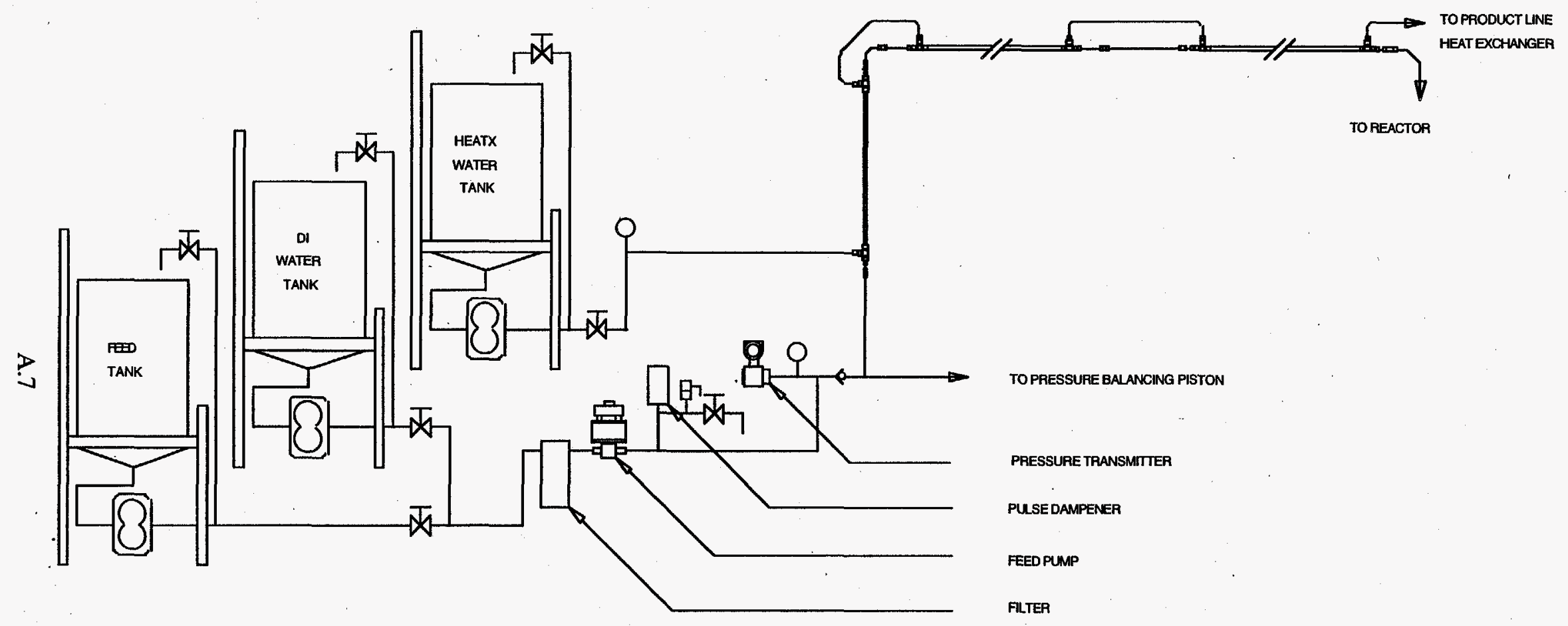

Figure A.4. Water and Feed Supply Tanks Plus Feed Pump 
鿷量

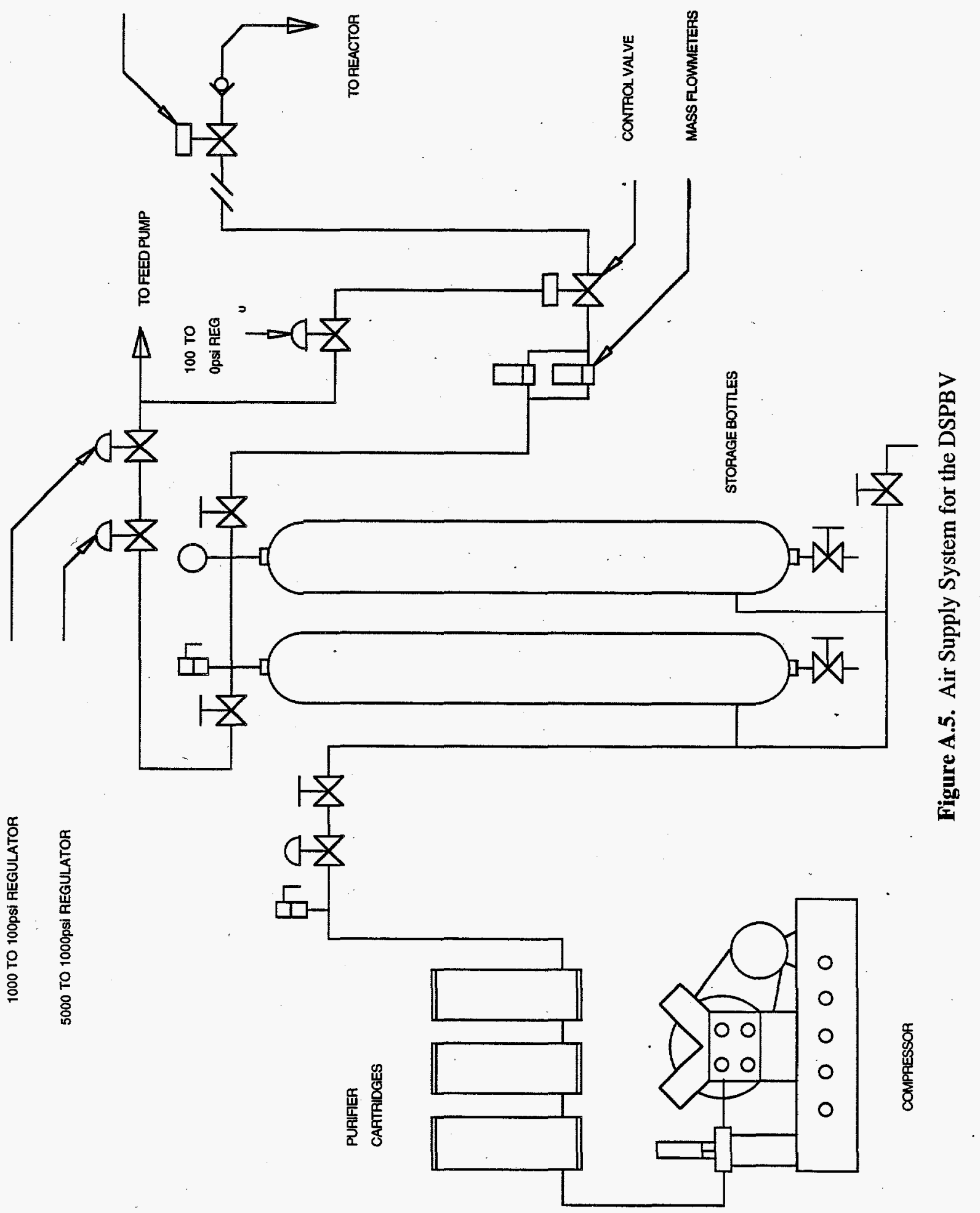




\section{A.2.5 Instrumentation}

Type $\mathrm{K}$ thermocouples are used to monitor fluid temperatures into, inside, and out of the reactor. Pressure transducers monitor pressures. Electronic mass flow meters monitor air flow. Process liquid flow rate is determined by weight loss from the feed tank and by a turbine flow meter. The air supply is monitored continuously using a mass flow meter.

An FMC electropneumatic (NIT 200) controller sets the control parameters (proportional/integral) on the air supply to the liquid pump. Another control module monitors differential pressure across the pressure balancing piston. The controller will bleed off Syltherm if the Syltherm pressure exceeds the process feed pressure by more than $100 \mathrm{psi}$. It will also decrease the process feed flow rate if process liquid feed pressure exceeds the Syltherm pressure by more than 100 psi. Components of the control system are shown in Figure A.6.

For data reduction purposes there are two computer systems and one stripchart recorder collecting process data. The backup computer (IBM ${ }^{\oplus}$ clone) collects raw data (voltages or milliamps). The primary computer (Macintosh ${ }^{\circledR}$ ) converts most signals to numbers meaningful for process control (temperatures/ pressures/flows). The primary computer does no real-time process control but does provide operators with immediate feedback on process variables and sounds audible alarms when conditions are beyond specified limits.

Table A.1 summarizes the process variables being monitored and their positions at the recording locations. The temperature measurement locations are shown in Figure A.7. Traditional pressure gauges provide backup readings for the reactor fluids and the air supply cylinders. 


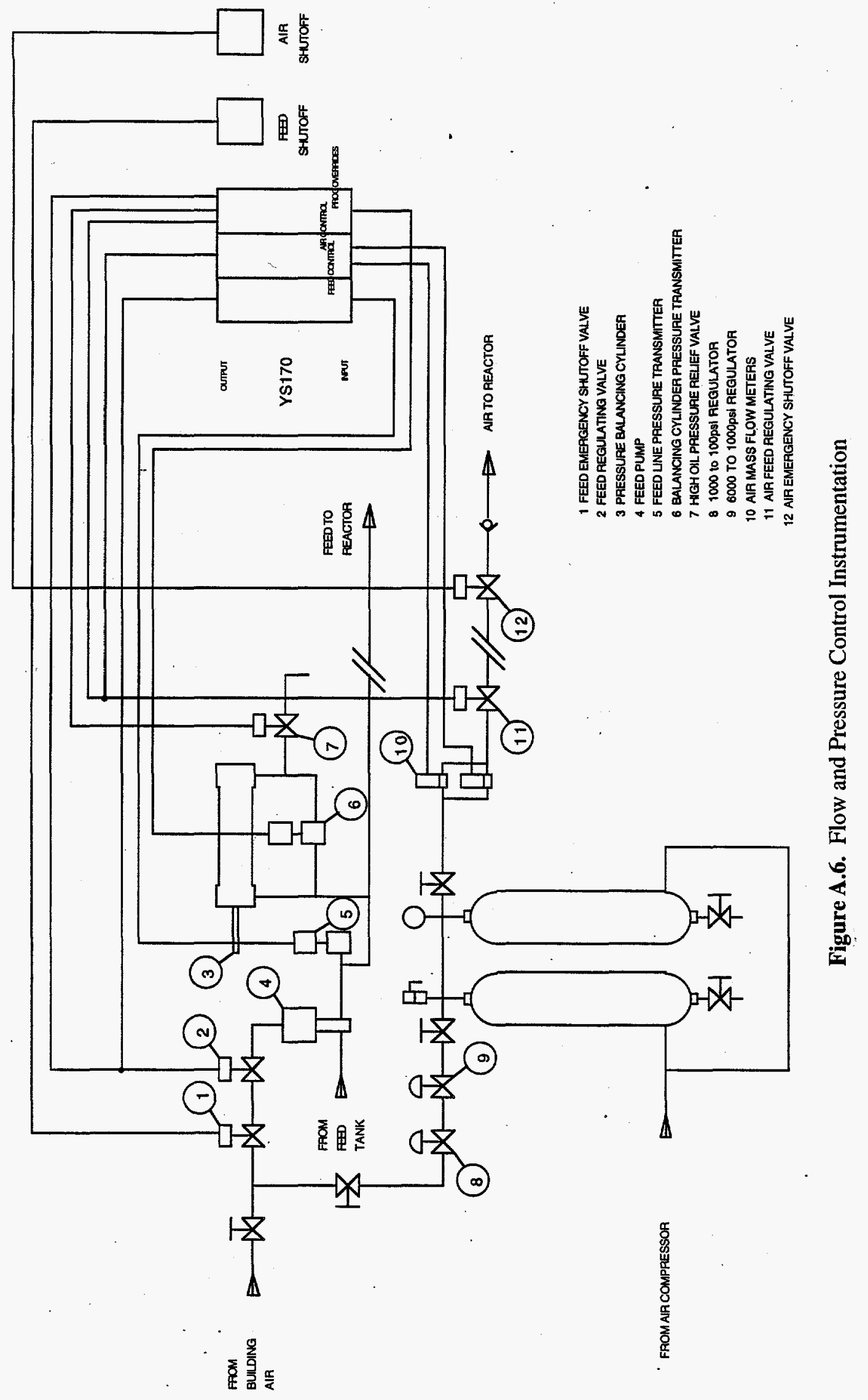

A. 10 
Table A.1. Process Variables Measured and Recorded

\begin{tabular}{|c|c|c|c|c|c|}
\hline Description & Abbr & $\begin{array}{l}\text { T/C difist } \\
\text { box }\end{array}$ & Recorder & IBM clone & Macintosh \\
\hline \multicolumn{6}{|l|}{ Thermocouples } \\
\hline Reactor liquid in @ 40" & RA40 & 1 & 1 & 1 & 1 \\
\hline Reactor liquid in @ 20" & RA20 & 2 & 2 & 2 & 2 \\
\hline Reactor liquid in @ 0" & RAO & 3 & 3 & 3 & 3 \\
\hline Reactor liquid out at 0" & RBO & 4 & 4 & 4 & 4 \\
\hline Reactor liquid out @ 20" & RB20 & 5 & 5 & 5 & 5 \\
\hline Reactor liquid out @ 40" & RB40 & 6 & 6 & 6 & 6 \\
\hline Syltherm 800 @ 10" & $\mathrm{RO10}$ & 7 & 7 & 7 & 7 \\
\hline Syltherm 800 @ 30" & $\mathrm{RO30}$ & 8 & 8 & 8 & 8 \\
\hline Syltherm 800@ 50" & RO50 & 9 & 9 & 9 & 17 \\
\hline Reactor skin @ 0" & RSO & 10 & 10 & 10 & 18 \\
\hline Reactor skin @ 20" & RS20 & 11 & 11 & 11 & 19 \\
\hline Reactor skin @ 40" & RS40 & 12 & 12 & 12 & 20 \\
\hline Heat exchanger 1 inlet & HX1A & 13 & 13 & 13 & 21 \\
\hline Heat exchanger 2 inlet & $H \times 2 A$ & 14 & 14 & 14 & 22 \\
\hline Heat exchanger 3 inlet & $\mathrm{H} \times 3 \mathrm{~A}$ & 15 & 15 & 15 & 23 \\
\hline Reactor inlet & RCTA & 16 & 16 & 16 & 24 \\
\hline Heat exchanger 4 inlet & $\mathrm{HX} 4 \mathrm{~A}$ & 17 & 17 & 17 & 25 \\
\hline Heat exchanger 5 inlet & $\mathrm{H} \times 5 \mathrm{~A}$ & 18 & 18 & 18 & 26 \\
\hline Heat exchanger 6 inlet & $\mathrm{HX6A}$ & 19 & 19 & 19 & 27 \\
\hline Letdown vessel inlet & LDVA & 21 & 20 & 20 & 28 \\
\hline Heat exchanger water inlet & HXWA & 22 & 21 & 21 & 29 \\
\hline Heat exchanger water outlet & HXWB & 20 & 22 & 22 & 30 \\
\hline spare & & 23 & & & \\
\hline spare & & 24 & & & \\
\hline \multicolumn{6}{|l|}{ Others } \\
\hline Air flow "A" & MFMA & & 23 & 23 & 9 \\
\hline Air Flow "B" & MFMB & & 24 & 24 & 10 \\
\hline Reactor pressure & RCTP & & 25 & 25 & 11 \\
\hline Letdown vessel pressure & LDVP & & 26 & 26 & 12 \\
\hline Process feed line pressure & LIQP & & 27 & 27 & 13 \\
\hline DP Syltherm/process feed & OWDP & & 28 & 28 & 14 \\
\hline Feed Weight in $\mathrm{Kg}$ & WTKG & & 29 & 29 & 15 \\
\hline Feed flow in GPH & FGPH & & 30 & 30 & 16 \\
\hline spare & & & 31 & 31 & \\
\hline spare & & & 32 & 32 & \\
\hline
\end{tabular}




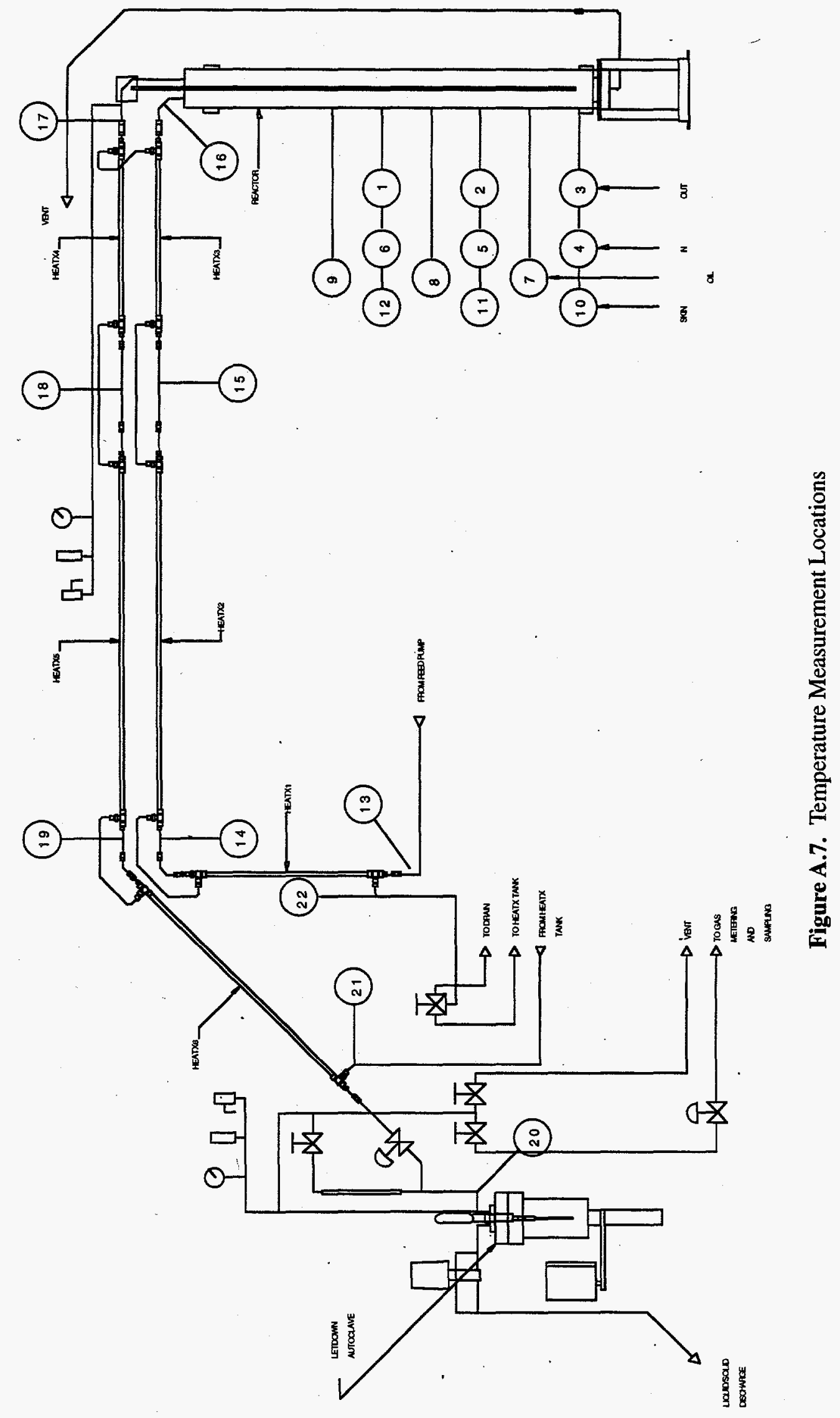

A. 12 


\section{Distribution}

No. of

Copies

Offsite

12 DOE Office of Scientific and Technical Information

8 DOE/Office of Technology Development Trevion II Building 12800 Middlebrook Road

Germantown, MD 20874

ATTN: S. M. Wolf

P. J. Ritzcovan

T. D. Anderson

J. M. Lankford

R. T. Parker

G. Boyd

S. T. Lien

W. Schutte

3 John Beller

EG\&G Idaho, Inc.

P.O. Box 1625

Idaho Falls, ID 83415-3900

4 DOE-HQ

Trevion II

12800 Middlebrook Rd.

Germantown, MD 20874

ATTN: J. Mobiuddin

L. M. Lankford

C. W. Frank

Technology Counterpart

DOE/Office of Tech. Dev.

Forrestal Building

U.S. Department of Energy

1000 Independence Ave. SW

Washington, DC 20585

ATTN: C. W. Frank

T. Williams

U.S. Department of Energy

Idaho Operations Office

850 Energy Dr.

Idaho Falls, ID 83401-1563
No. of

Copies

G. Allen

Department 6607/MS 0756

Sandia National Laboratory

P.O. Box 5800

Albuquerque, NM 87185-0756

Dr. Steve Rice

Sandia National Laboratory

Livermore, CA 64551-0969

Mary Clair Stoddard

Sandia National Laboratory

Livermore, CA 64551-0969

J. B. Berry

Oak Ridge National Laboratory

P.O. Box 2008

Oak Ridge, TN 37831-6330

Dr. Robert Mesmer

Oak Ridge National Laboratory

P.O. Box 2008, 4500-S MS 6110

Oak Ridge, TN 37831

Dr. Dan Wilson

Oak Ridge National Laboratory

P.O. Box 2008, 4500-S, MS 6156

Oak Ridge, TN 37830-6156

Dr. Steven J. Buelow

Los Alamos National Laboratory

P.O. Box 1663 MS J567

Los Alamos, NM 87545

Dr. Richard Oldenberg

Los Alamos National Laboratory

P.O. Box 1663, CLS-4, MS-J567

Los Alamos, NM 87545

Dr. Theodore Krause

Argonne National Laboratory Chemical Technology Division 9700 S. Cass Avenue

Argonne, IL 60439 
No. of

$\underline{\text { Copies }}$

W. Bliss

Environmental Management Div.

Reynolds Electrical and Eng. Co., Inc.

2501 Wyandotte

P.O. Box 98521

Las Vegas, NV 89193-8521

J. Corones

AMES Laboratory

329 Wilhelm Hall

Iowa State University

Ames, IA 50011

R. Craig

HAZWRAP

P.O. Box 2003, MS 7606

Oak Ridge, TN 37831-7606

N. Egan

Program Development Division

MSE Inc.

P.O. Box 3767

Butte, Montana 59702

Richard Kirts

Naval Civil Engineering Laboratory

560 Laboratory Drive

Port Hueneme, CA 93043-4328

Dr. George Nauflett

Indian Head Division

Code 2810G

Naval Surface Warfare Center

101 Strauss Ave.

Indian Head, MD 20640

Prof. Jennifer Brand

Dept of Chemical Engineering

222 Avery Laboratory

University of Nebraska-Lincoln

Lincoln, NE 68588-0126
No. of

Copies

Dr. David Ross

SRI International

PS 269

Menlo Park, CA 94025

Dr. Robert Shaw

Chemical \& Biological Sciences

Division

U.S. Army Research Office

RTP, NC 27709-2211

Prof. Earnest Gloyna

College of Engineering

University of Texas

Austin, TX 78712

Dr. W. Killilea

MODAR, Inc.

14 Tech Circle

Natick, MA 01760

Dr. Michael Modell

Model Development Corporation

Framingham, MA 01701

Prof. Jefferson W. Tester

Massachusetts Institute of

Technology Energy Laboratory

Room E40-455

77 Massachusetts Avenue

Cambridge, MA 02139

\section{Onsite}

DOE Richland Operations Office

D. E. Trader

K8-50

Westinghouse Hanford Company

J. D. Berger

L0-18

ICF Kaiser Hanford

C. T. $\mathrm{Li}$

B4-40 
No. of

Copies

24 Pacific Northwest Laboratory

L. M. Bagaasen P7-43

E. G. Baker P8-38

T. M. Brouns K9-08

G. S. Deverman K3-69

M. R. Elmore K3-75

A. G. Fassbender (5) K1-34

S. R. Gano P8-38

E. O. Jones K3-75

R. J. Robertus (5) K3-75

S. C. Slate

K9-14

Publishing Coordination

Technical Report Files (5) 